Nikolai Pchelin,

Simone-Christiane Raschmann

\title{
Turfan manuscripts in the State Hermitage - a rediscovery
}

Abstract: The article presents the results of a close cooperation of colleagues from the State Hermitage and the Göttingen Academy of Sciences (Union Catalogue of Oriental Manuscripts). 23 fragments of manuscripts and block prints in five different languages (Chinese, Old Uighur, Sanskrit, Tibetan, and Syriac) are described in detail. Almost all of them could be identified. They stem from the four German Turfan expeditions (19021914) and were housed in the Museum für Völkerkunde (Berlin) for exhibition reasons, i.e. they belong to the most important findings of these expeditions. Nevertheless some of these fragments have never been published before. For a long time it was thought that they belong to the losses during World War II. Now they have been re-discovered in the depot of the State Hermitage. In the appendix an Old Uighur fragment of the Säkiz Yükmäk Yaruk is edited. It belongs to the re-discovered texts and was known up-to-now only from some quotations in an early edition.

Key words: State Hermitage, German Turfan expeditions, Museum für Völkerkunde (Berlin), manuscript, block print, scroll, folded book, amulet, illumination, Chinese, Old Uighur, Sanskrit, Tibetan, Syriac, Säkiz Yükmäk Yaruk.

The impressive exhibition "The Caves of One Thousand Buddhas. Russian Expeditions on the Silk Road", organized in close co-operation in 20082009 by the Hermitage Museum and the Institute of Oriental Manuscripts on the occasion of the 190 anniversary of the foundation of the Asiatic Museum deeply enhanced the long lasting cooperation between the German and Russian scholars working in the field of Central Asian studies, and Turfan studies in particular, and consequentially in 2012 an agreement of cooperation in the field of Turfan studies between the Director-General of the State Hermitage, the President of the Prussian Cultural Heritage Foundation and the President of the Berlin Brandenburg Academy of Sciences and Humanities was signed in March 2013. The long tradition goes back even to that time,

(C) Nikolai Georgievich Pchelin, State Hermitage Museum, Saint Petersburg

(C) Simone-Christiane Raschmann, Akademie der Wissenschaften zu Göttingen, Katalogisierung der Orientalischen Handschriften in Deutschland, Alttürkische Handschriften aus den Turfanfunden 
when Russia and Germany were organizing and undertaking their archaeological expeditions to East Turkestan (todays Xinjiang Autonomous Region in the PR of China) at the end of the 19th and the beginning of the 20th cc. When the Berlin Museum für Völkerkunde started its efforts to join the exploration of the ruined sites of East Turkestan they highly benefited from the already earned experiences by their Russian colleagues and even were offered manifold support in organizing and completing the German Turfan expeditions. Although the plans for joined Russian-German campaigns failed, we have knowledge of a broad exchange of information concerning the results of their respective campaigns, the on-going research on the findings, which was in certain fields even conducted in close cooperation and the exchange of publications in this particular field.

When the above mentioned exhibition was opened to the public in December 2008, it presented not only the results of the Russian archaeological activities in Central Asia, but the State Hermitage for the first time also put on display wall paintings which were brought from Turfan and the surrounding areas to Berlin by the four German Turfan expeditions (1902-1914) and which have been kept in the archives of the State Hermitage since the end of WW II. ${ }^{1}$

It was already in autumn 2002 when Marianne Yaldiz, the at-that-time Director of the Berlin Museum of Indian Art (todays Museum für Asiatische Kunst and former Museum für Völkerkunde) together with the Museum's conservator were invited by the Director-General of the State Hermitage Mikhail Piotrovsky to have a look at the Berlin collections of Indo-Asian art in the Hermitage stores. ${ }^{2}$ Back in Berlin she immediately gave an oral report to the Berlin Turfan research group at the Academy and let them know that there are also several precious Turfan manuscripts in different languages and scripts from the Berlin collection preserved amongst the objects from Berlin. The announcement of the surviving of all these objects was applauded by the community of Central Asian scholars worldwide, although the details of the single objects were not clear at this moment.

In the course of the exhibition and during visits to St. Petersburg in order to take part at several international conferences like that of "Dunhuang Studies: prospects and problems for the coming second century of research" (September 2009), the 53. Permanent International Altaistic Conference (July 2010) and "Sergei Fedorovich Oldenburg: Scholar and Academic Research Organizer" (September 2013) the members of the Berlin Turfan study

\footnotetext{
${ }^{1}$ Peshchery tysiachi budd, 426-455: Prilozhenie 2. Pamiatniki iz kollektsii Griunvedelia.

${ }^{2}$ See the report of this visit, written by Marianne Yaldiz, cf. YALDIZ 2005, 2-3.
} 
groups of the Berlin and the Göttingen Academy of Sciences were offered not only the chance to view the whole collection of wall paintings from the German Turfan expeditions preserved in the depot of the State Hermitage, but also a number of fragments which belonged to the Berlin Turfan text collection in former times. In cooperation with Peter Zieme we were able to make a provisional inventory list of these fragments and collected as much data as possible from every item. Back in Berlin we were able to identify the up to this time thought to be lost during WW II Turfan fragments. They all belong to this limited part of Turfan fragments which used to stay in the Berlin Museum für Völkerkunde mostly for exhibition reasons, when in 1926 the vast majority of the Turfan texts was handed over to the newly founded "Orientalische Kommission" of the Prussian Academy of Sciences for philological research and publication. ${ }^{3}$ These circumstances already make clear that the rediscovered Turfan texts in the State Hermitage belong to the most important findings of the German Turfan expeditions and it is no wonder that most of them were already published or at least quoted by the so-called first generation of Turfan researchers shortly after their discovery in the first decades of the 20th c.

In the following we will give a detailed overview of the manuscripts and block prints from the Berlin Turfan collection in the depot of the State Hermitage, which, as seen in the photos, are very poorly preserved.

\section{The rediscovered manuscripts and block prints}

Altogether up to now 23 fragments of manuscripts and block prints are registered in the provisional inventory list. Among them ten fragments of Chinese manuscripts, one fragment with Sanskrit text on one side and Chinese on the opposite side, seven fragments of Old Uighur manuscripts and four fragments of Old Uighur block prints, one Syriac fragment and one Tibetan fragment. Some of the fragments are illustrated.

What follows is a description of the single items with known references and catalogue entries. Some of the fragments have been unpublished yet. A detailed study and edition of these fragments (Chinese, Syriac and Tibetan) we put aside for the specialists in these fields. ${ }^{4}$

\footnotetext{
${ }^{3}$ Cf. GRAPOW 1950, 1-29.

${ }^{4}$ We have to thank our colleagues Peter Zieme, Klaus Wille and Tsuneki Nishiwaki for their friendly support. Thanks to them some preliminary information concerning the Chinese, Sanskrit and Syriac fragments could be added here.
} 
(1) Chinese manuscript of the 佛説仁王護國般若波羅蜜多經巻上 Foshuo renwang huguo banruoboluomiduo jing (juan shang): Taishō vol. 8, no. 244, 829a $11-829$ c 22 (identified by Tsuneki Nishiwaki).

Fragment of a scroll.

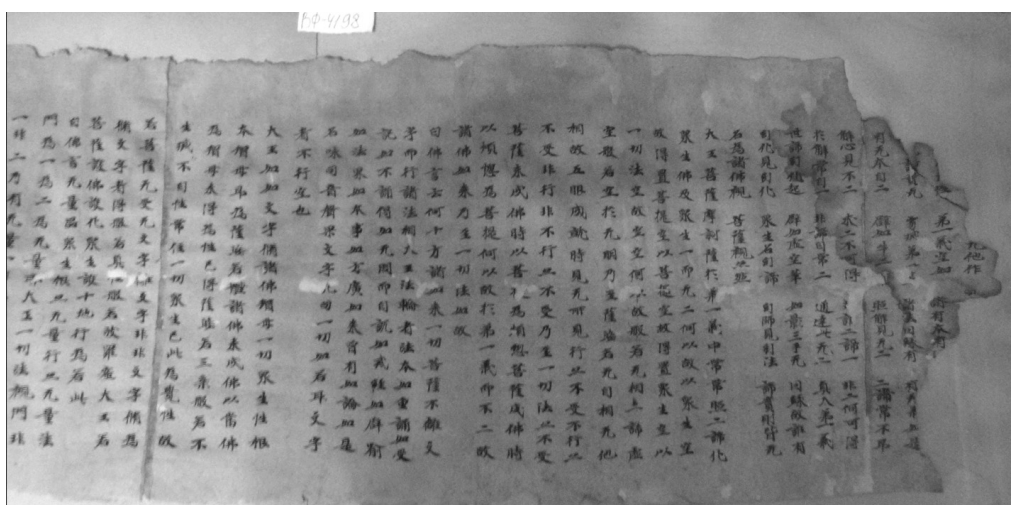

Pl. 1. ВФ-4198, beginning of the fragment. By courtesy of the State Hermitage

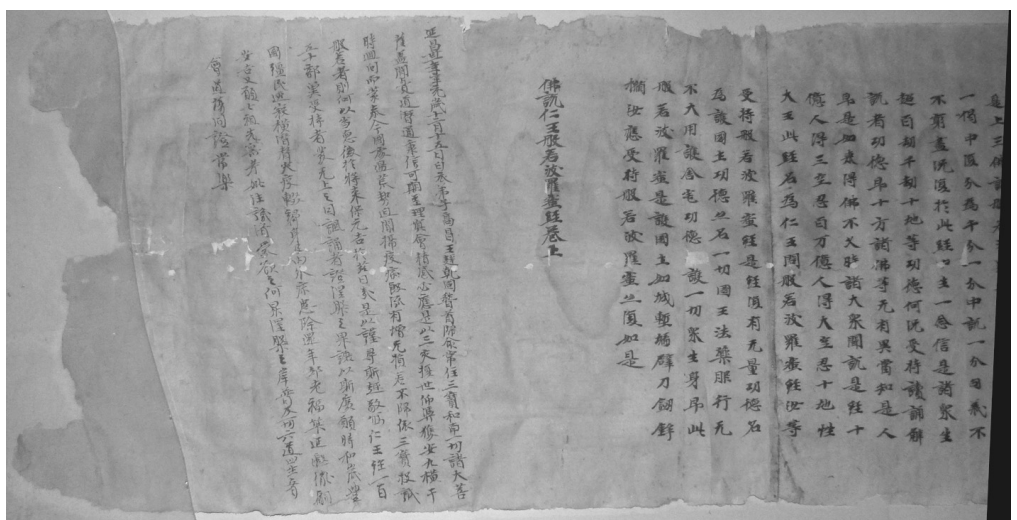

Pl. 2. ВФ-4198, final part of the fragment. By courtesy of the State Hermitage

Inventory number (in the State Hermitage): ВФ-4198.

Old finding number (given in the course of the four German Turfan expeditions):

Yarchoto No. 6

Size: $129.1 \mathrm{~cm} \times 26.0 \mathrm{~cm}^{5}$

Number of lines: 59 text lines +1 title lines +8 lines colophon (script of smaller size).

Reference: NISHIWAKI 2008, 389-400.

${ }^{5}$ This fragment consists of four sheets of paper which were glued together. The size of each sheet of paper is: approximately $41.5 \mathrm{~cm} \times 26.0 \mathrm{~cm}$. 
(2) Chinese manuscript of the 現在十方千五百佛名一巻 Xianzai shifang qianwubai foming (juan yi): Taishō vol. 14, no. 442, 317b 1 - 318a 7 (identified by Tsuneki Nishiwaki).

Fragment of a scroll.

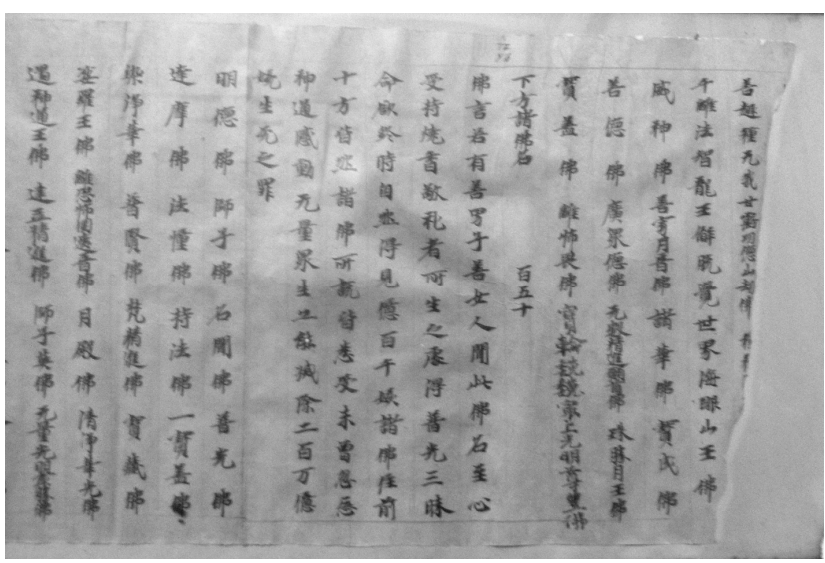

P1. 3. ВФ-4199, beginning of the fragment. By courtesy of the State Hermitage

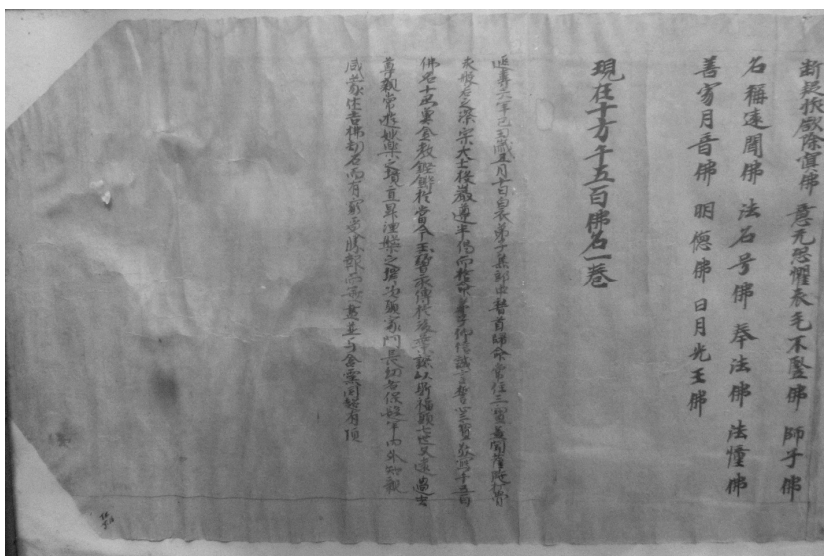

P1. 4. ВФ-4199, final part of the fragment. By courtesy of the State Hermitage

Inventory number: ВФ-4199.

Old finding number: T II Y 16

Size: $158.8 \mathrm{~cm} \times 26.5 \mathrm{~cm}^{6}$

Number of lines: 52 text lines +1 final title line +5 colophon lines (smaller size script).

${ }^{6}$ This fragment consists of four sheets of paper which were glued together. The size of each sheet of paper is: approximately $44.5 \mathrm{~cm} \times 26.5 \mathrm{~cm}$. 
(3) Amulet $(v u)$ with text lines in Chinese and Old Uighur. Fragment of a scroll. ${ }^{7}$

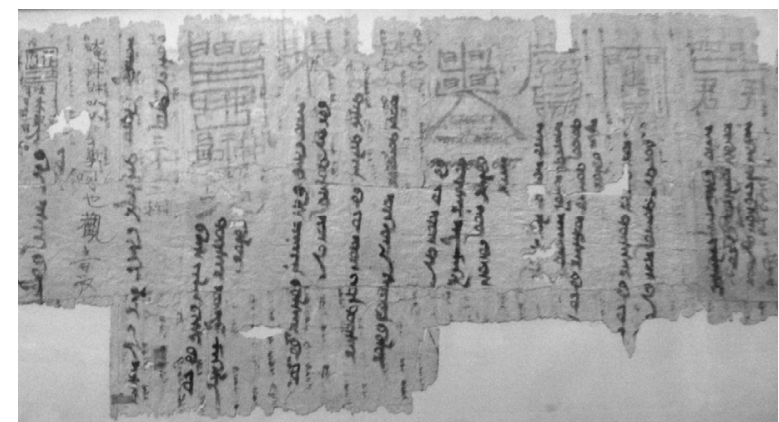

Pl. 5. ВФ-4203, middle part of the fragment. By courtesy of the State Hermitage

Inventory number: ВФ-4203.

Old finding number: T II Y 51

Additional note: Koje $7 .^{8}$

Size: $192.6 \mathrm{~cm} \times 29.8 \mathrm{~cm}^{9}$

Note: Old photographs of the text are preserved in the Museum für Asiatische Kunst:

B 2288-2291.

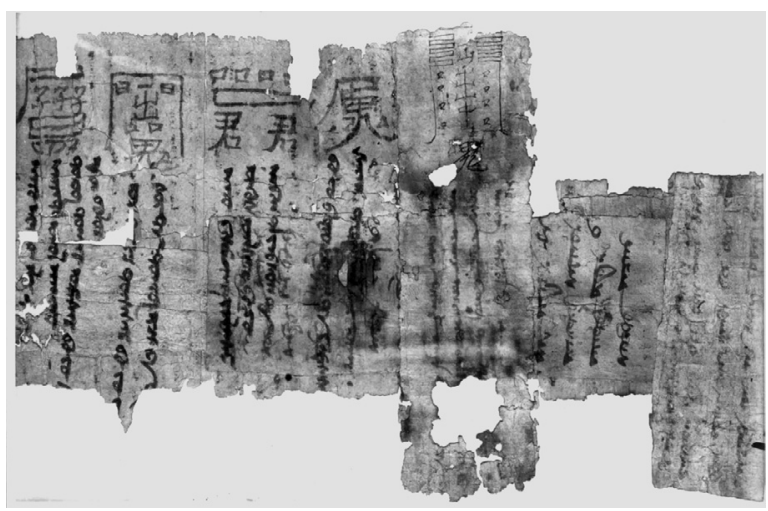

Pl. 6. Photograph B 2288. By courtesy of the Museum für Asiatische Kunst - Staatliche Museen zu Berlin.

${ }^{7}$ The back side of this fragment is covered, but it can be safely reported that there was another text written on the verso of this scroll.

${ }^{8}$ This note was added in order to remember the location where the fragment was exhibited in the Berlin Museum für Völkerkunde before WW II. These notes were most probably added during the packaging of the Museum's objects in order to prepare their transport to places for safekeeping during the war.

${ }^{9}$ Cf. RACHMATI 1937, 73. He also added some notes concerning the format and the quality of the paper: "Die Rolle ist aus groben und zum Teil kleinen Papierfetzen zusammengeklebt worden". 
References: RACHMATI 1937, 37-38 (No. 27: T. II Y. 51.); ZIEME 2005, 182-184

(I. „Die sieben Guanyin“ und Amulette) + plates XCII-XCIII.

Catalogue entry: KNÜPPEL 2013, 197-199 (catalogue No. 250-253: B 2288-2291).

(4) The Old Uighur Säkiz Yükmäk Yaruk.

Manuscript. Fragment of a scroll.

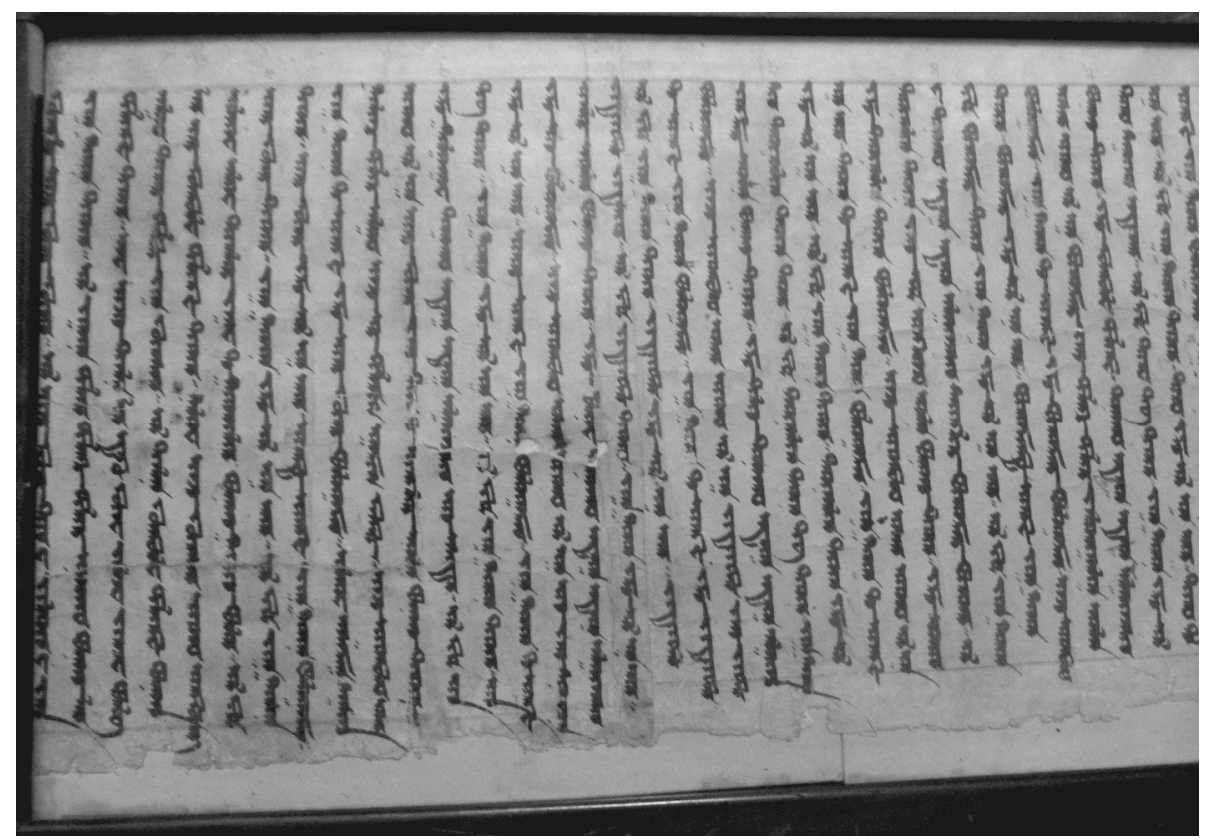

P1. 7. ВФ-4201, beginning of the fragment. By courtesy of the State Hermitage

Inventory number: ВФ-4201.

Old finding number: T III TV 61 / T III 84 (**U9232).

Number of lines: 131 lines.

Size: $176.5 \mathrm{~cm} \times 28.7 \mathrm{~cm}$.

Reference: BANG/GABAIN/RACHMATI 1934: 99, 100-101, passim (B25).

Catalogue entry: RASCHMANN 2012, 87-88 (catalogue No. 079: *U9232 ${ }^{10}$ ).

${ }^{10}$ This signature marks that this fragment was preserved in the Berlin Turfan collection before WW II according to previous publications and was thought to be lost during the war. At the time of the compilation of the catalogue volume in question it's surviving and present day safe custody in the State Hermitage was not known to the compiler of the catalogue volume. Now a second asterisk* is added (**U9232) in the registers to signify this special circumstance. 
(5) The 妙法蓮華經 Miao fa lian hua jing: Taishō vol. 9, no. 262, p. 10c 26 - 11c 2 (identified by Tsuneki Nishiwaki).

Manuscript. Fragment of a scroll.

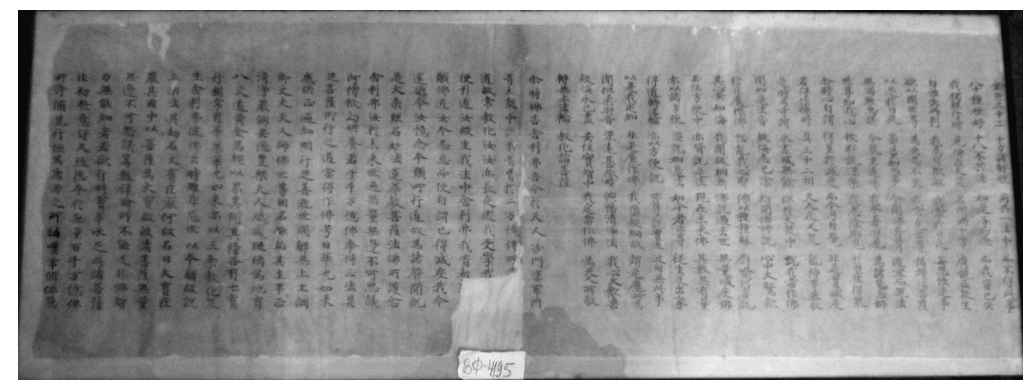

Pl. 8. ВФ-4195. By courtesy of the State Hermitage

Inventory number: ВФ-4195.

Old finding number: [ ] Yarchoto No. 6.

Former inventory number: (IB 6288). ${ }^{11}$

Additional note: ящ 835 , акт 111 от $27 / \mathrm{X}$ п. $20 .{ }^{12}$

Number of lines: 43 lines.

Size: $78.8 \mathrm{~cm} \times 28.5 \mathrm{~cm}$.

(6) The Old Uighur version of the Sarva-durgati-pariśodhana-uṣniṣavijayā-dhāraṇi with glosses in Brāhmī script and a Chinese pagination: 十九.

Block print. Fragment of a folded book.

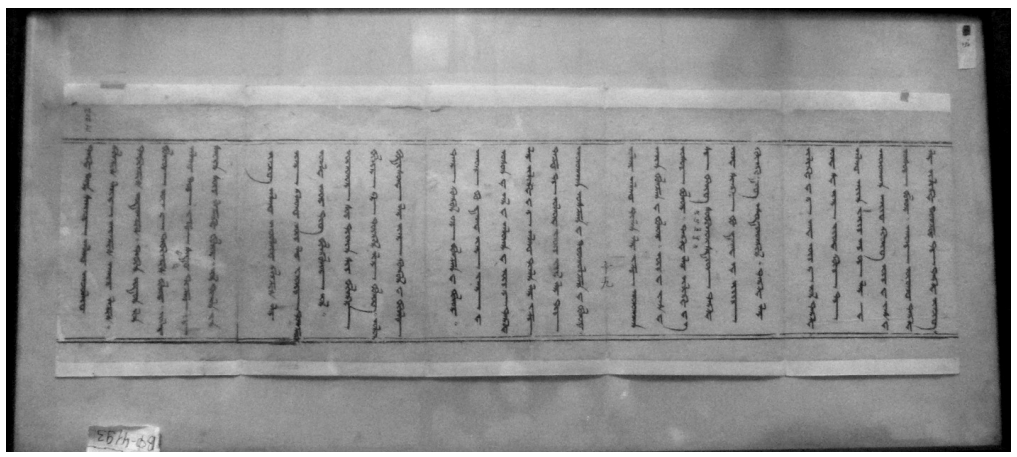

Pl. 9. ВФ-4193. By courtesy of the State Hermitage

${ }^{11}$ This old German inventory number was added to the manuscript during the process of the inventory in the State Hermitage. It was possibly a mistake, because another item bears this number, too. It is still clearly visible that this label is the original German one.

12 These data report details concerning the transport of the fragments from Berlin to St. Peterburg. 
Inventory number: ВФ-4193.

Old finding number: T III M 207 / T II S $92^{13}$ (**U9365).

Number of lines: 5 folios with 6 lines each, i.e. in total 30 lines.

Size: $56 \mathrm{~cm} \times 15.7 \mathrm{~cm}$.

Length of the lines: $11.8 \mathrm{~cm}$.

Reference: MÜLLER 1911, 47-50. ${ }^{14}$

Catalogue entry: YAKUP/KNÜPPEL 2007, 167-168 (catalogue no. 213: *T III M 207b, f. a-e).

(7) Fragment of an Old Uighur Buddhist text concerning the confession of sins commissioned by a lay woman Üträt by name.

Manuscript.

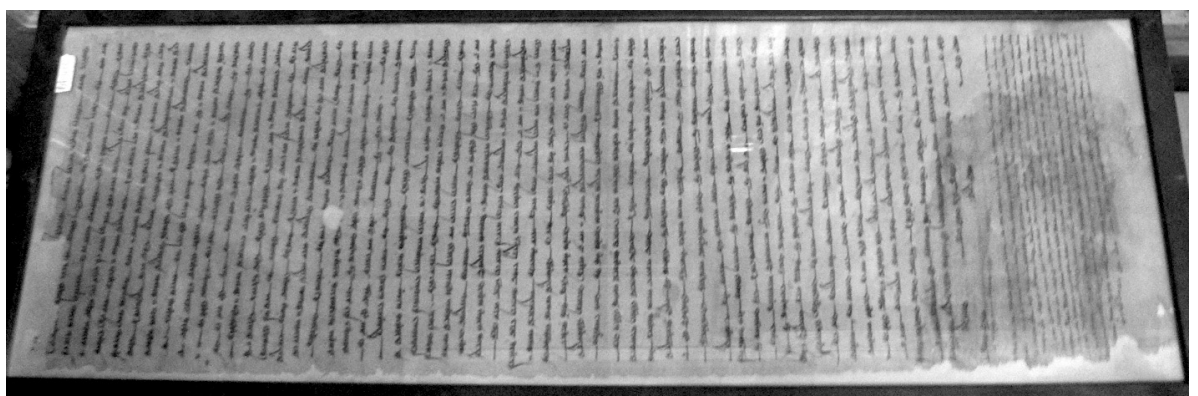

Pl. 10. ВФ-4192. By courtesy of the State Hermitage

Inventory number: ВФ 4192.

Old finding number: T II Y 48 (**U9090).

Number of lines: 58 lines +14 lines colophon (script in smaller size).

Size: $115 \mathrm{~cm} \times 33.2 \mathrm{~cm}$.

\footnotetext{
${ }^{13}$ This number is cancelled.

${ }^{14}$ The text is published under the old finding number T III M 207b. The visible part of the fragment in the wooden frame shows only the lines $1-30$ of this edition. But, on the right margin it is possible to see that the fragment was folded. The second part is not visible because the verso is covered.
} 
12

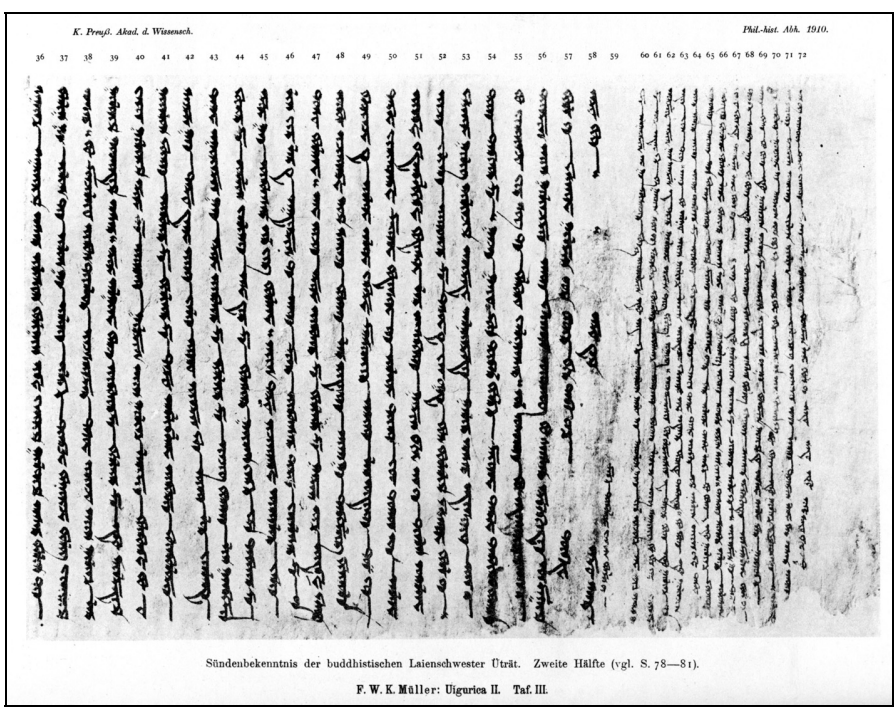

Pl. 11. Facsimile after F.W.K. Müller: Uigurica II, pl. III (see reference).

Reference: MÜLLER 1911, 76-83 (text 7) + pl. III-III.

Catalogue entry: WILKENS 2003, 258 (catalogue No. 308: **U9090). ${ }^{15}$

(8) Chinese manuscript of the Buddhanama-sütra without illustrations.

Fragment of a scroll.

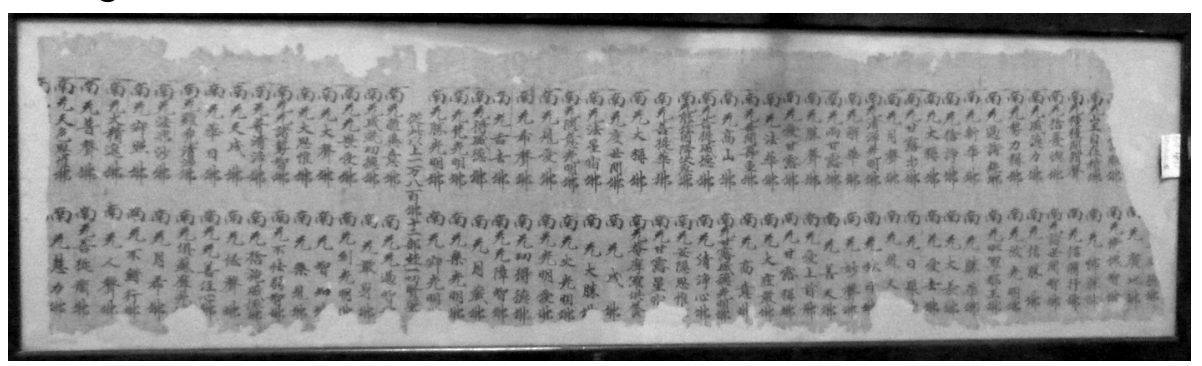

Pl. 12. ВФ-4197. By courtesy of the State Hermitage

Inventory number: ВФ-4197.

Old finding number: [ ] Y 66

Former inventory number: IB 6702.

Additional note: ящ 835 , акт 91 от $27 / \mathrm{X}$ п. $22 .{ }^{16}$

Number of lines: 51 lines.

Size: $117.5 \mathrm{~cm} \times 29.7 \mathrm{~cm}$.

\footnotetext{
${ }^{15}$ Concerning the signature **U9090 see the explanation given for **U9232 in fn. 10.

${ }^{16}$ For an explanation see fn. 12 .
} 
(9) Chinese manuscript of the 佛説大辯邪正經 Foshuo dabian xiezheng jing: Taishō vol. 85, no. 2893, p. 1412c 22 - 1413a 28 (identified by Tsuneki Nishiwaki; cf. Pelliot 2263).

Fragment of the 1st scroll.

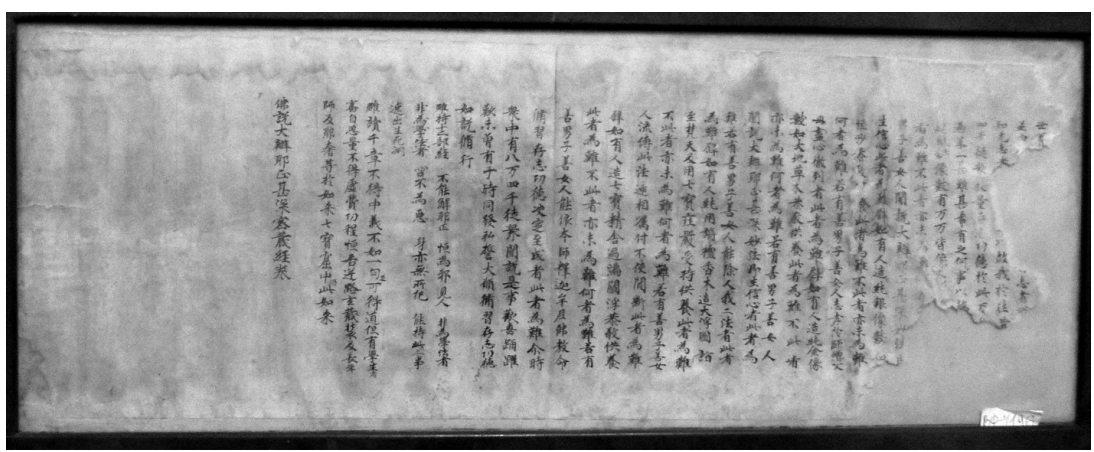

Pl. 13. ВФ-4196. By courtesy of the State Hermitage

Inventory number: ВФ 4196.

Number of lines: 33 lines +1 headline (title). Each line has 17 characters.

Size: $77.8 \mathrm{~cm} \times 27.7 \mathrm{~cm}^{17}$

Length of the lines: $19.5 \mathrm{~cm}$.

(10) Old Uighur version of the Sitātapatrā-dhāraṇi with Brāhmī glosses.

Block print. Fragment of a folded book.

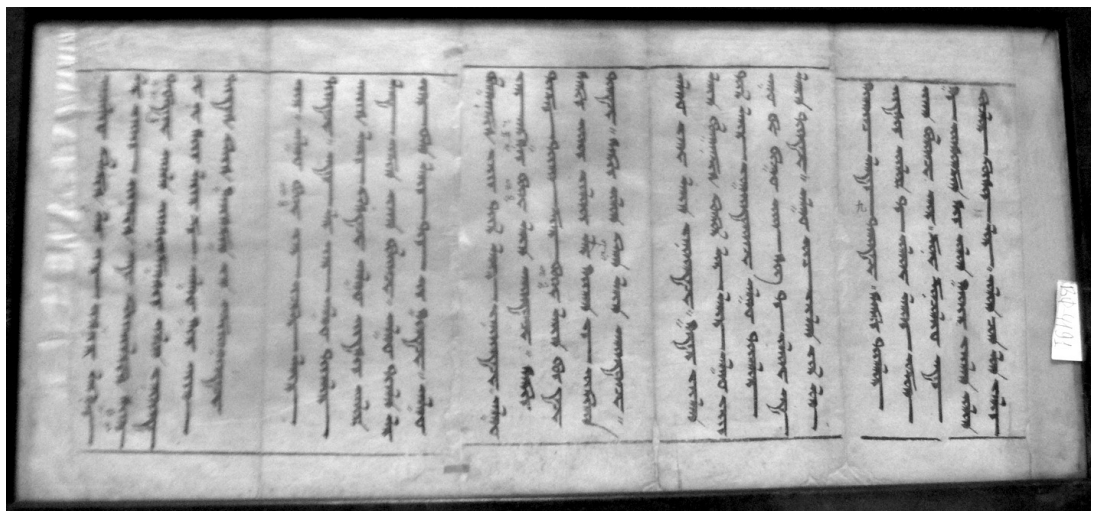

Pl. 14. ВФ-4191 а.д. Вy courtesy of the State Hermitage

${ }^{17}$ It is visible that the fragment consists of two sheets of paper glued together overlapping each other, as usual. 
Inventory number: ВФ 4191 а.д.

Old finding number: T III M 225.

Number of lines: 25 lines in total (5 pages with 5 lines each).

Size: $55.8 \mathrm{~cm} \times 27.5 \mathrm{~cm}$.

Note: According to MÜLLER (1911) the preserved manuscript consists of three fragments:

**U9203: T III M 225 (6.-7.), Chinese pagination 八

**U9204: T III M 225 (8.-9.)

**U9205: T III M 225 (10.), Chinese pagination 九. ${ }^{18}$

References: MÜLLER 1911, 57-59; RÖHRBORN / RÓNA-TAS 2005, 257-259.

Catalogue entry: YAKUP/KNÜPPEL 2007, 51 (catalogue No. 29: *T III M 225 (6)

*T III M 225(7)), 52 (catalogue No. 31: *T III M 225(8) *T III M 225(9)), 53 (catalogue No. 33: *T III M 225(10).

(11) Unpublished Syriac text. Handwritten manuscript in scroll(?) format.

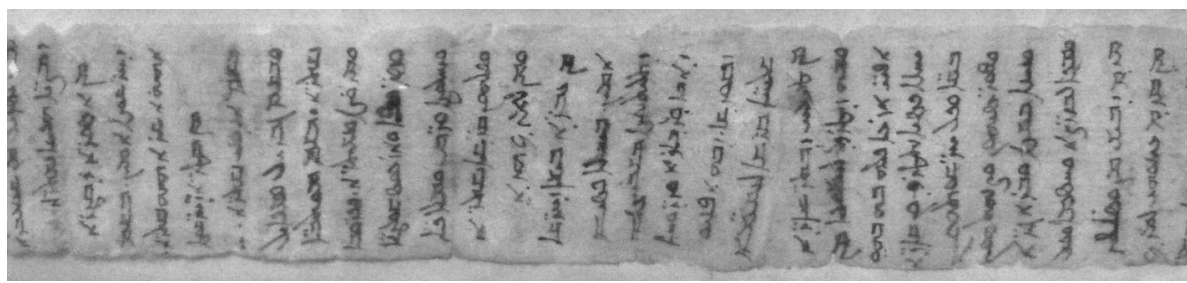

P1. 15. ВД-524, detail. By courtesy of the State Hermitage

Inventory number: ВД 524.

Old finding number: [T] D 134 / D II 134

Number of lines: 78 lines.

Size: $89.5 \mathrm{~cm} \times 7.0 \mathrm{~cm}$.

Note: Photos of this manuscript are preserved in the Archives of the Museum für Asiatische Kunst, Berlin-Dahlem (nos. B 1055-1060, 1777-1779, 1786).

${ }^{18}$ Concerning the signatures **U9203-**U9205 see the explanation given for **U9232 in fn. 10 . 


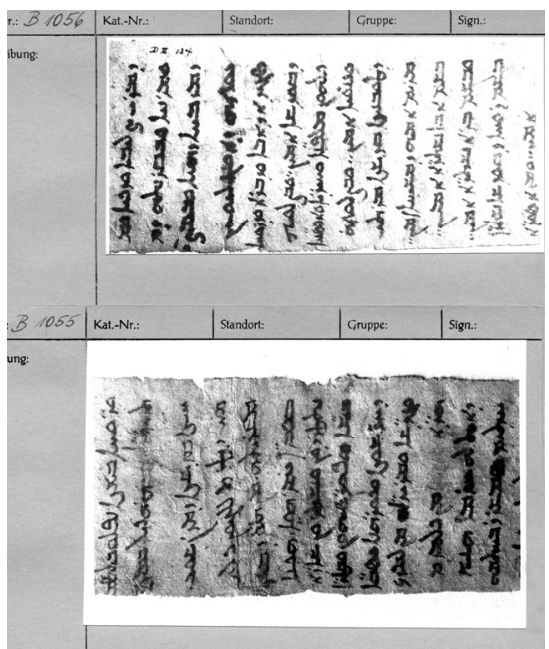

Pl. 16. B 1055-1056

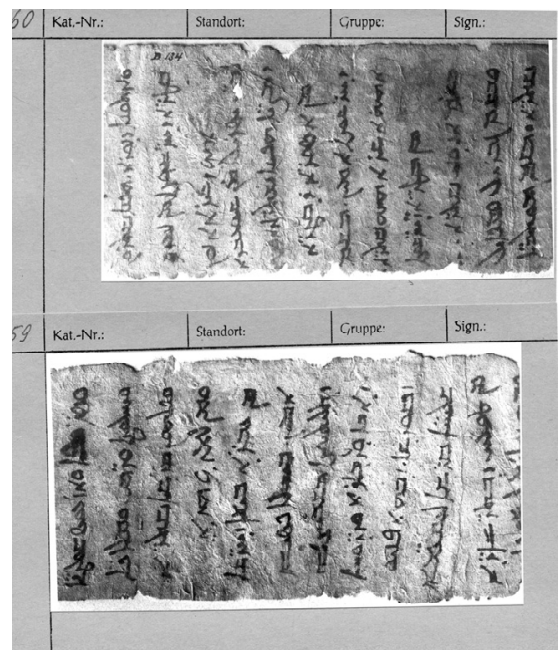

Pl. 18. B 1059-1060

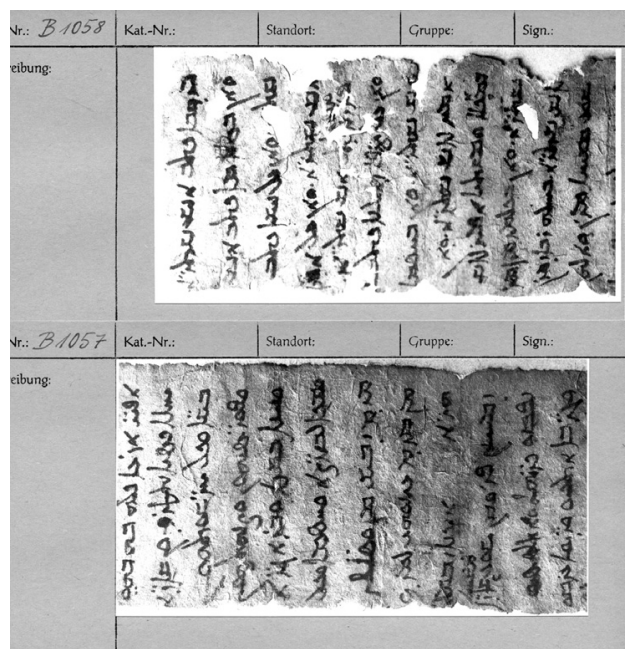

Pl. 17. B 1057-1058

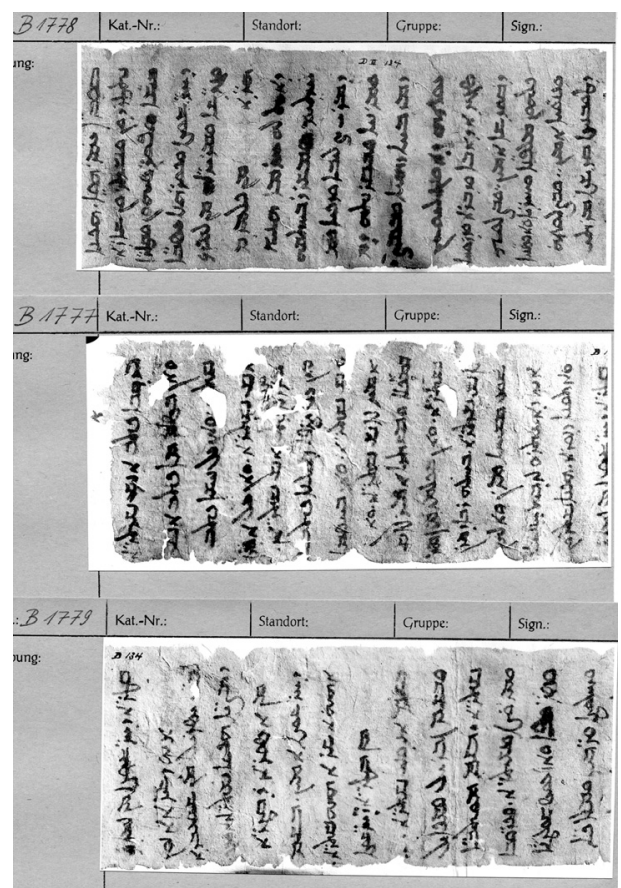

Pl. 19. B 1777-1779 


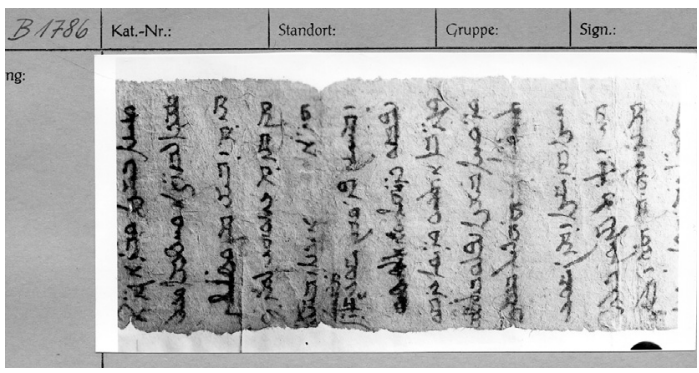

Pl. 20. B 1786

(12) The Old Uighur version of the 佛頂心 大陀羅尼 Fo ding xin da tuo luo ni.

Block print. Fragment of a folded book.

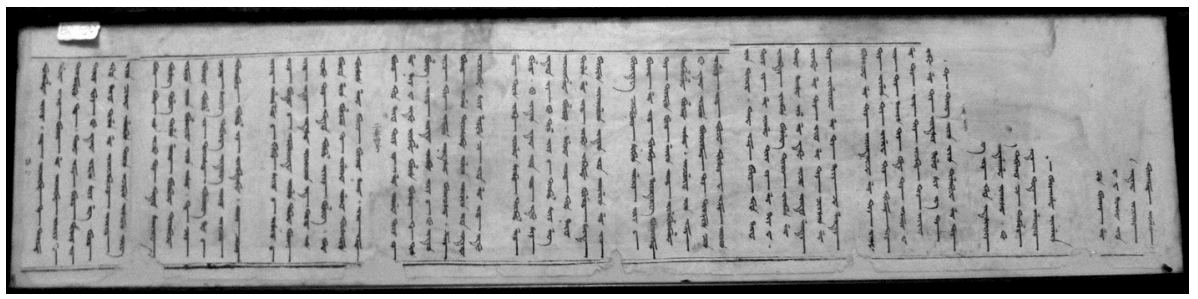

P1. 21. ВД-527. By courtesy of the State Hermitage

Inventory number: ВД 527.

Old finding number: [T II] S 92.

Number of lines: 58 lines +2 lines of Chinese pagination.

Size: $93.8 \mathrm{~cm} \times 20.8 \mathrm{~cm}$.

Note: A handwritten transcript of the fragment $(* * \mathrm{U} 9202)^{19}$ is preserved in the archive of the Berlin Turfan collection (BBAW).

${ }^{19}$ Concerning the signature **U9202 see the explanation given for **U9232 in fn. 10 . The transcript presents the text of the lines $138-185$ in the edition of KARA/ZIEME 1986. The final part of the handwritten transcript (lines 186-195) is missing. 


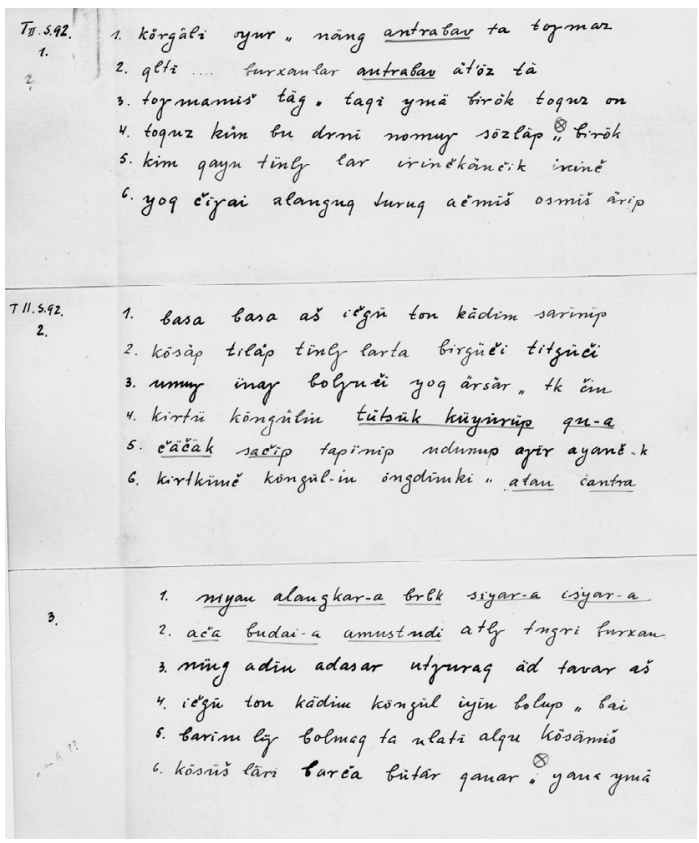

Pl. 22. **U9202 (1.-3.)

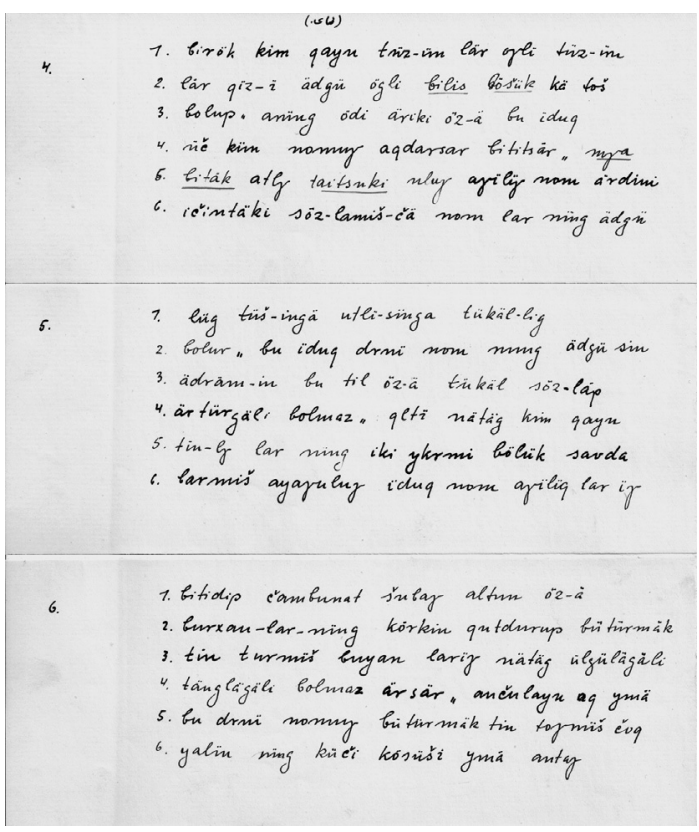

P1. 23. **U9202 (4.-6.) 


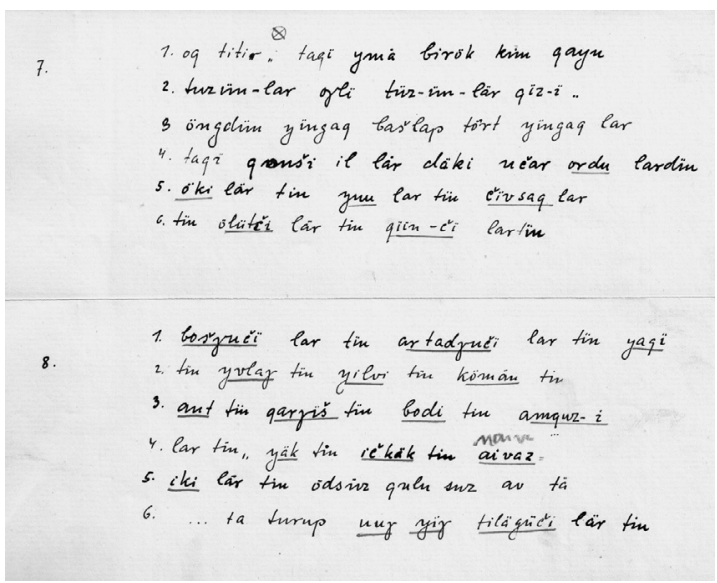

P1. 24. **U9202 (7.-8.)

Reference: KARA/ZIEME 1986, 320, 329-330 (K: T II S 92, lines 138-196). ${ }^{20}$ Catalogue entry: YAKUP 2008, 33-35 (catalogue nos. 8-9: *U9202). ${ }^{21}$

(13) Chinese manuscript of the 摩訶般若波羅蜜經 卷十八Pañcavimiśatisāhasrikā[mahā]prajñā-pāramitāsūtra: Taishō vol. 8, no. 223, 351c 16352c 2 (identified by Tsuneki Nishiwaki).

\section{Fragment of the 18 th scroll. ${ }^{22}$}

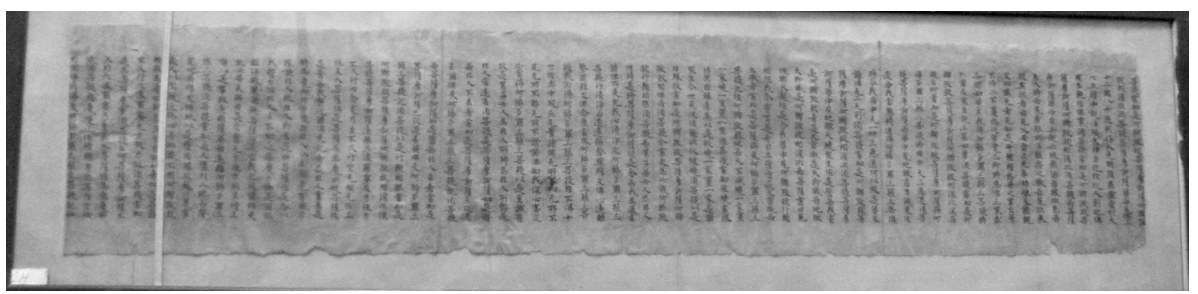

Pl. 25. ВД-523. By courtesy of the State Hermitage

Inventory number: ВД-523.

Old finding number: T II Y 20.

Additional note (on the back): Koje $2 .^{23}$

${ }^{20}$ By reading the original text some minor corrections are possible: (139) $k$ (a)ltı nätäg burhan-lar; (177) ordo-lardın; (179) kıyn-čc-lardın.

${ }^{21}$ Concerning the signature *U9202 see the explanation given for **U9232 in fn. 10 .

${ }^{22}$ The fragment consists of three sheets of paper glued together. The size of each sheet is: $51.5 \times 25.5 \mathrm{~cm}$.

${ }^{23}$ For an explanation of this note see fn. 8 . 
Number of lines: 69 lines, 17 characters per line. ${ }^{24}$

Size: $125.0 \mathrm{~cm} \times 25.5 \mathrm{~cm}$.

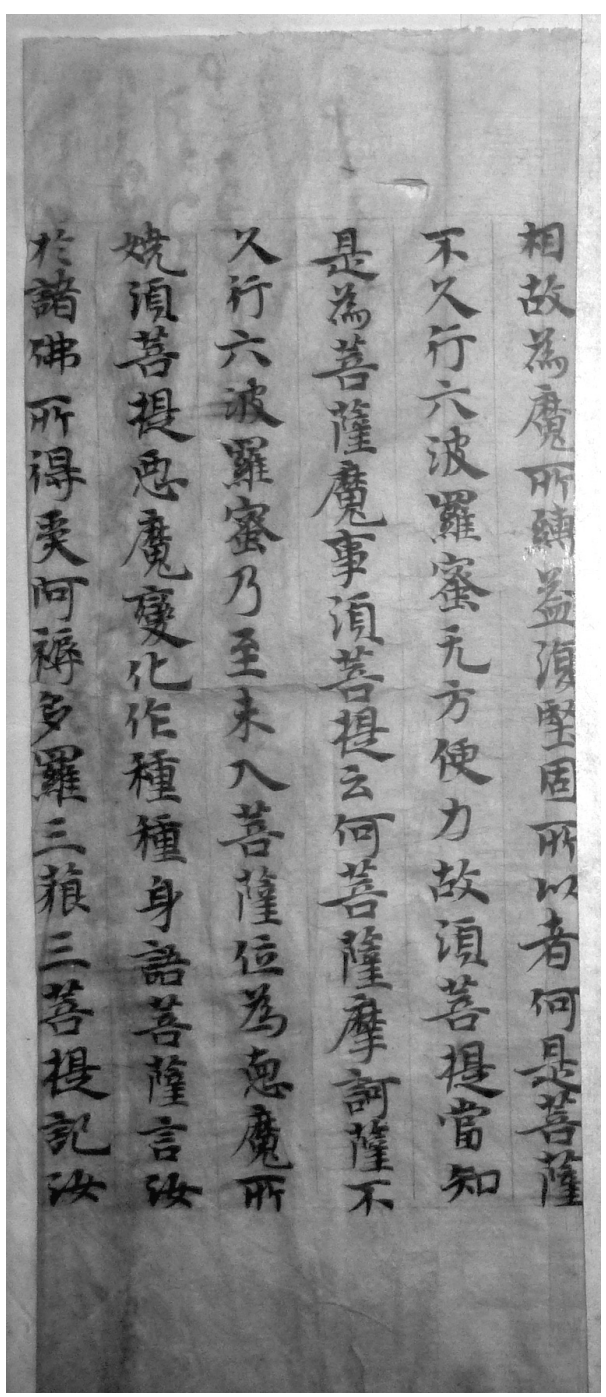

P1. 26. ВД-523, final part of the fragment. ${ }^{25}$ By courtesy of the State Hermitage

${ }^{24}$ Between the last Chinese lines at the end of the fragment Old Uighur text lines from the back are clearly visible. Unfortunately the back is covered.

${ }^{25}$ For additional notes concerning this part of the fragment see fn. 22. 
(14) The Old Uighur $X^{v} \overline{a s t v a ̄ n i f f t . ~}$

Fragment of a manuscript in scroll(?) format.

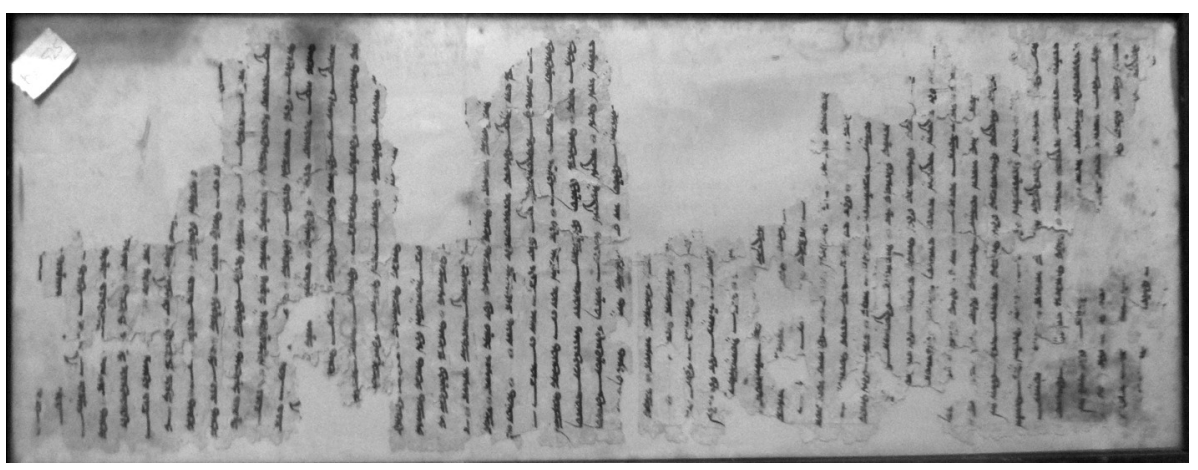

Pl. 27. ВД-525. By courtesy of the State Hermitage

Inventory number: ВД-525

Old finding number: T II Y 60a, T II Y 60b (**U9120, **U9121).

Number of lines: 52 lines.

Punctuation: a black colon with red frame.

Size: $91.3 \mathrm{~cm} \times 34.0 \mathrm{~cm}$.

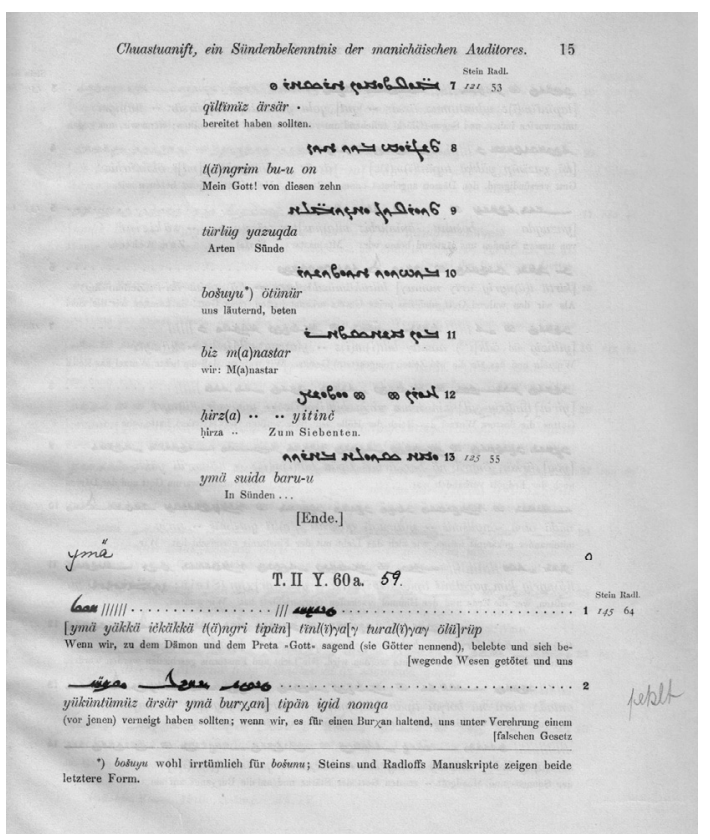

Pl. 28. Reprint from LE COQ 1911: Chuastuanift, 15. 


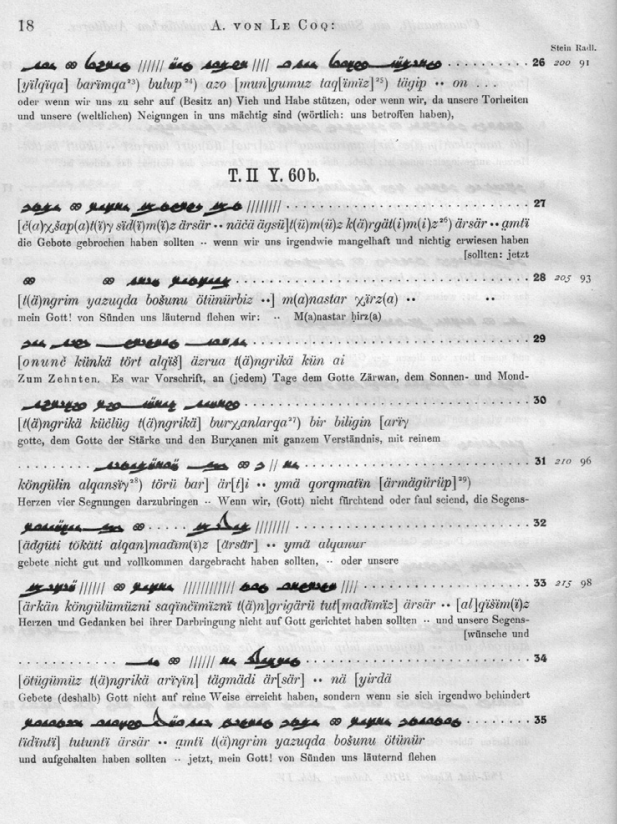

Pl. 29. Reprint from LE CoQ 1911: Chuastuanift, 18.

References: LE COQ 1911, 15-20; ZIEME 1975, 19; ÖZBAY 2014, 246-251

Catalogue entries: WILKENS 2000, 351: catalogue No.*399 (*U9120); 355: catalogue No.*405 (*U9121). ${ }^{26}$

(15) The Old Uighur Kuan-ši-im Pusar (Saddharmapuṇdarīka-Sūtra).

Fragment of a manuscript in scroll format.

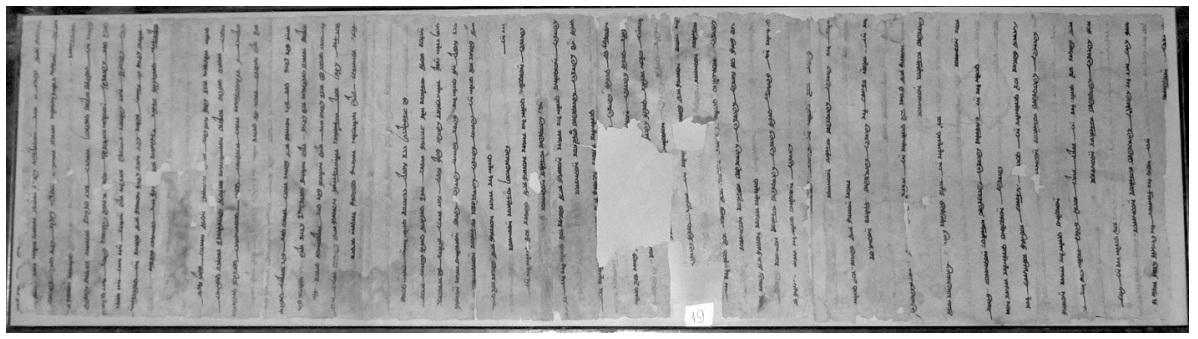

Pl. 30. ВД-526. By courtesy of the State Hermitage

${ }^{26}$ Concerning the signatures $* *$ U9120 and $* *$ U9121 see the explanation given for **U9232 in fn. 10. 
Inventory number: ВД-526.

Old finding number: T II Y 10 / T II Y 18 / T II Y 18 / T II Y 10 (**U9039).

Additional note (on the back): Koje $4 .^{27}$

Number of lines: recto: 66 lines in total ${ }^{28}$; verso: 3 lines. ${ }^{29}$

Size: $117.5 \mathrm{~cm} \times 31.0 \mathrm{~cm}$.

Note: A black-and-white photograph showing the lines 1-13 of the fragment with the old finding signature T II Y 10 is preserved in the Archives of the Berlin Turfan collection (BBAW). On the back the following note is to be read: "T II Y 10.17.18. quanši im pusar. Original im Museum Raum X. Koje 4. Originalgröße.“

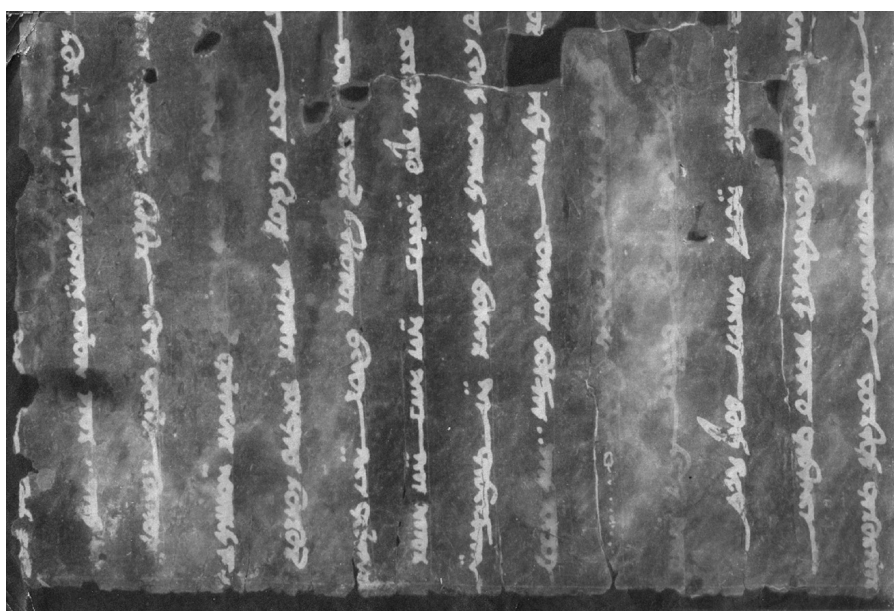

P1. 31. T II Y 10.

By courtesy of the Berlin-Brandenburgische Akademie der Wissenschaften (Turfansammlung)

Note: In the edition of MÜLLER 1911 (17-18, lines 35-37) the following text can be added according to ВД-526:

35 hormuz t(ä)Đri körkin [körtgürü nomlayur kutgarur : birök] mahešvar ulug

36 [är]klig t(ä)yri körkin kur[tulgu tınlıglar ärsär konši im] pusar ol tınl(1)g

37 -larka ulug ärklig t(ä)Đri körk[in körtgürü nomlayur kutga]rur : bo birök

38 ärklig t(ä)Đri körkin kurtulgu [ ]///[ tınlıg]

39 -lar ärsär : konši im pusar [ol tı]nl(1)glar-ka ärklig t(ä)yri körkin [körtgürü]

${ }^{27}$ For an explanation of this additional note see fn. 8 .

${ }^{28}$ The lines or part of the following lines are written in red ink (sometimes almost faded out): $3,8-10,14-15,20-23,28,29,31,32-33,33,34,35,37-38,40,43,44-45,48,50,52$, $53,54-55,56,58-59,61-62,64$. In the quoted text lines $(35-41)$ the text passage in question is underlined.

${ }^{29}$ In the edition the following note is added: „Auf der Rückseite Bemerkung von anderer Hand in Pinselschrift". 
40 nomlayur kutgarur : birök [

] $/ / / / / / / / / / /{ }^{30}[$

]

41 körkin kurtulgu tınl(1)g[lar] ärsär konši im pusar ol tınl(1)glar-ka

After line 41 the text of T II Y 18 and T II Y 10, line 1ff. (cf. Müller 1911, 18) follows.

Reference: MÜLLER 1911, 14-20 (text no. 3); TEKIN 1960, 12-14 (11. 71-117).

Catalogue entry: ÖZERTURAL 2012, 89-90: catalogue No. 85 (*U9039). ${ }^{31}$

(16) The Old Uighur Sitātapatrā-dhāraṇī with occasional added Brāhmī glosses.

Block print. Three Fragments of a folded book mounted in a wooden frame.

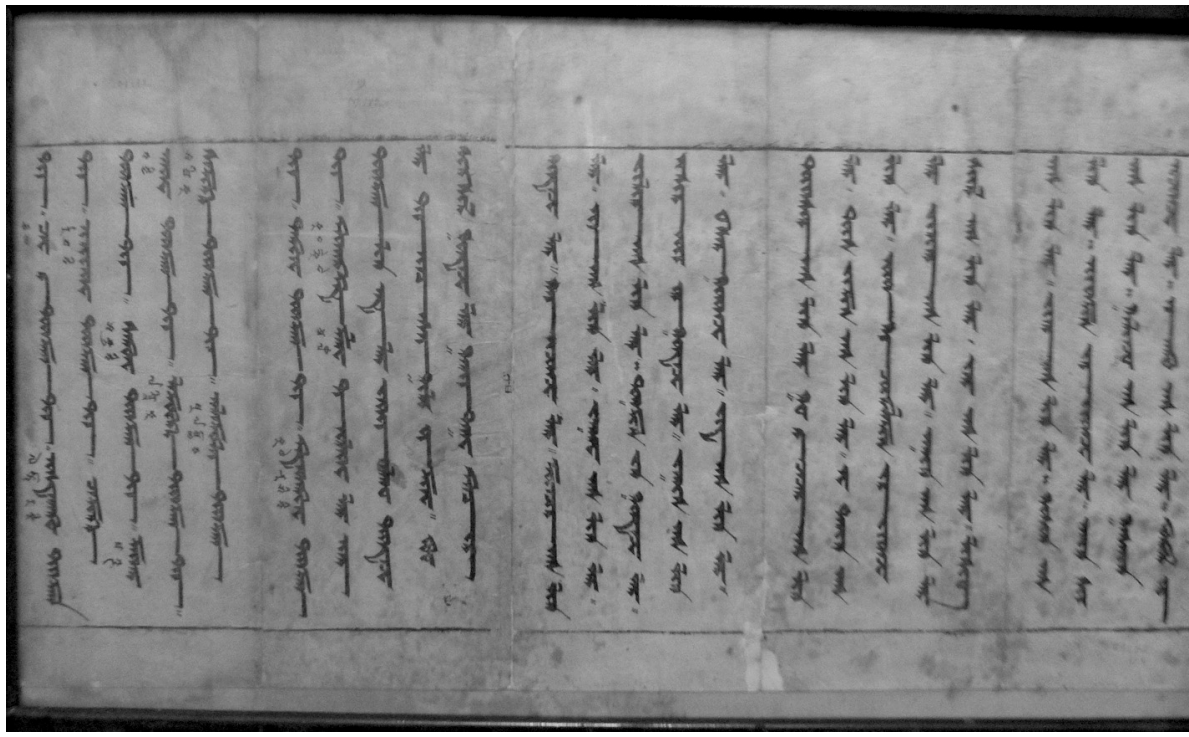

Pl. 32. ВД-531, beginning of the joined fragments. By courtesy of the State Hermitage

\footnotetext{
${ }^{30}$ The text is almost faded out.

${ }^{31}$ Concerning the signature *U 9039 see the explanation given for **U9232 in fn. 10
} 


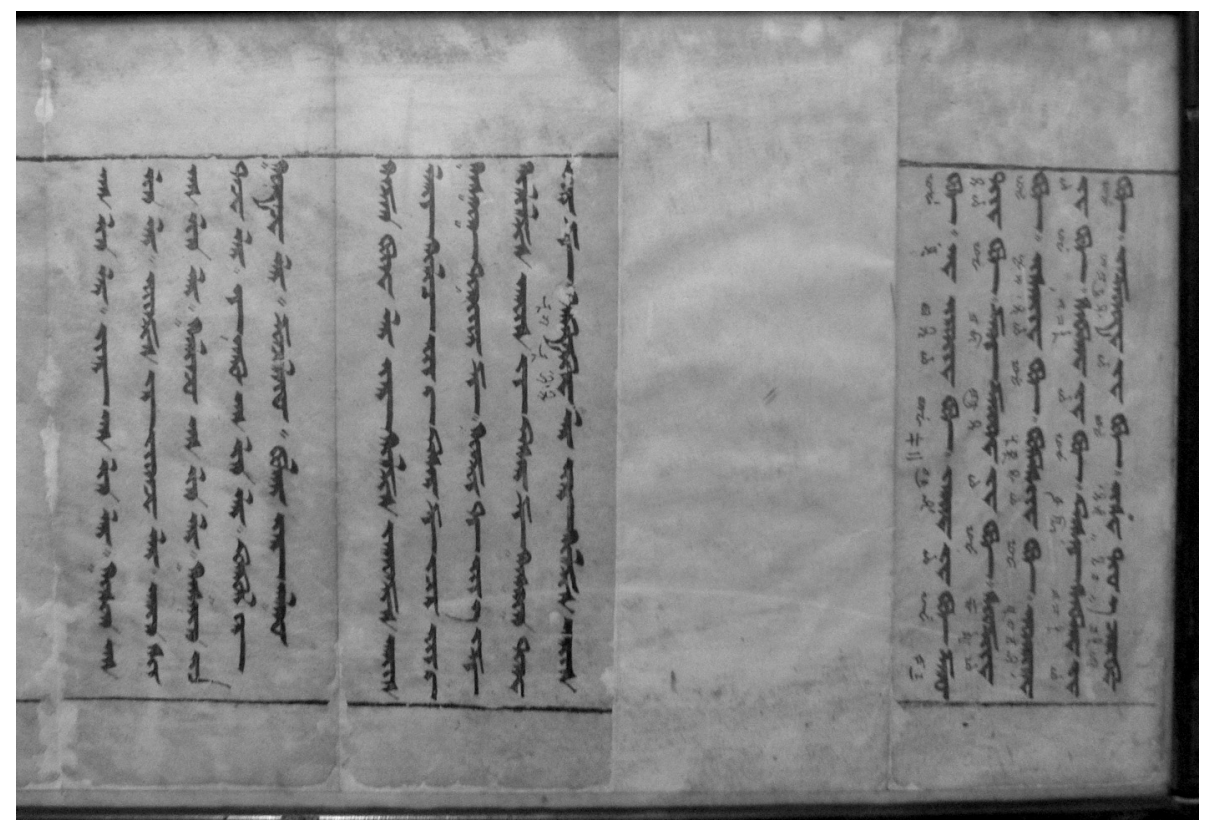

Pl. 33. ВД-531, the final part of the joined fragments. By courtesy of the State Hermitage

Inventory number: ВД-531.

Old finding number: T III M 182 / T III M 231.5 / T III M 231.

Additional note (on the wooden frame): Raum X, Koje $5 \mathrm{r}^{32}$

Number of lines: 70 lines and Chinese pagination.

Size: $170 \mathrm{~cm} \times 30.5 \mathrm{~cm}$.

Note: According to MÜLLER (1911) the preserved manuscript consists of three fragments:

(1) $)^{33}$ T III M 182 (**U9206), Chinese paginations 二(?)十四 “24(?)”, 二十五 “25”

$(2)^{34}$ T III M 231.5 (**U9207), Chinese pagination 十四 “14”

$(3)^{35}$ T III M 231 (**U9208), Chinese pagination 二十二 ,22“.

References: MÜLLER 1911, 57-59; LE COQ 1919, 105-107 + pl. 5 (T III M 231 ${ }^{36}$ ); RÖHRBORN/RONA-TAS 2005, 263-265, 268-269 (1l. 207-216, 217-237, 284-289).

Catalogue entries: YAKUP/KNÜPPEL 2007, 61 (catalogue No. 47: *T III M 182), 6263 (catalogue No. 49: *T III M 231), 66 (catalogue No. 54: *T III M 231).

${ }^{32}$ For an explanation of this additional note see fn. 8 .

${ }^{33}$ Size: $100.5 \times 29.5 \mathrm{~cm}$.

${ }^{34}$ Size: $44.8 \times 30.5 \mathrm{~cm}$.

${ }^{35}$ Size: $30.5 \times 11 \mathrm{~cm}$. As an exception, all the five text lines preserved on this fragment are completely annotated with Brāhmī glosses.

${ }^{36}$ Le Coq described the fragment as follows: „Vier noch zusammenhängende Blätter eines Faltbuchs (jedes Blatt $30.4 \times 11.2 \mathrm{~cm}$ ) weißes rauhes Papier. Anfang fehlt“. 
(17) Tibetan manuscript of the Irk bitig. Fragment of a scroll.

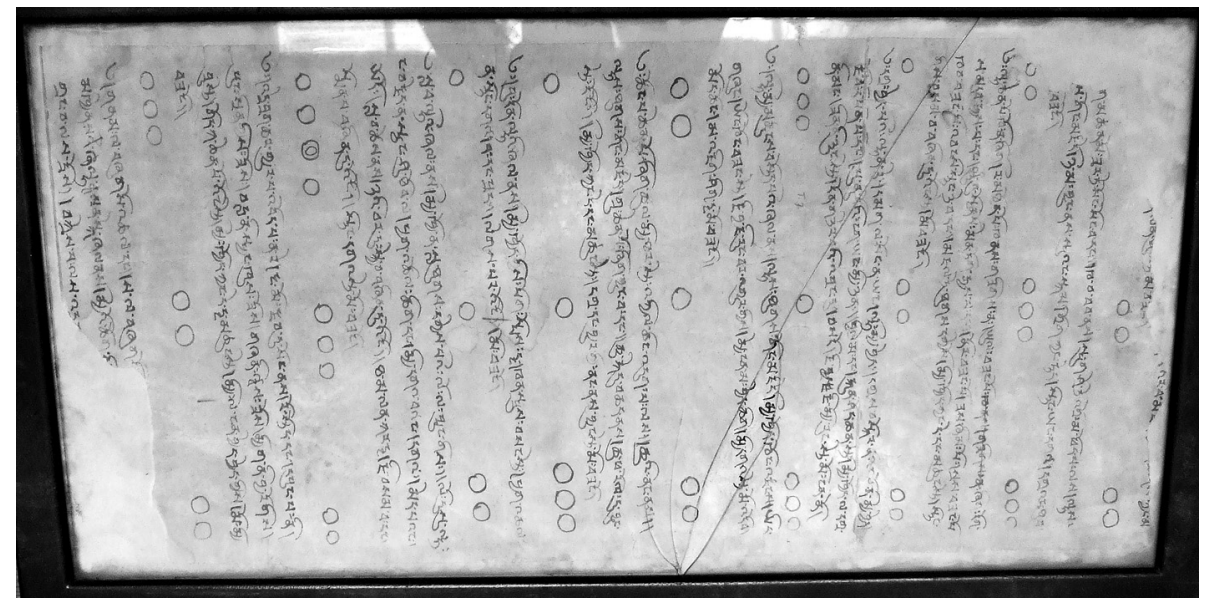

Pl. 34. ВФ-4724. By courtesy of the State Hermitage

Inventory number: ВФ-4724.

Old finding number: T. 7.

Number of lines: 31 (recto).

Size: $57.3 \mathrm{~cm} \times 26.7 \mathrm{~cm}$.

Note: There is a stick attached to the frame with a note: "Rückseite Chinesisch". Nowadays the verso(?) side of the manuscript is not accessible, because it is covered.

A report on this fragment is present in "the report of the Oriental Commission" ("Bericht der Orientalischen Kommission") dated January 1929, cf. TAUBE 1980, $85 \mathrm{fn}$. 1. According to this reference the fragment in question belongs to the series of Tibetan fragments TibHT 31 - TibHT 35 which are preserved in the Berlin Turfan collection, cf. idp.bbaw.de/database/. 
(18) Chinese manuscript of the 妙法蓮華經 Miao fa lian hua jing (Saddharmapundarīka-Sütra) on the recto (Taishō vol. 9, no. 262). In addition, 3 lines in Brāhmī script are written on the upper margin of the Chinese manuscript. Different texts in Brāhmī script on the verso: 11. 6-32: Prasādapratibhodhava (= Śatapañcāśatka) of Mātṛceța (verse 1-13c, identified by Klaus Wille).

Two fragments of a scroll.

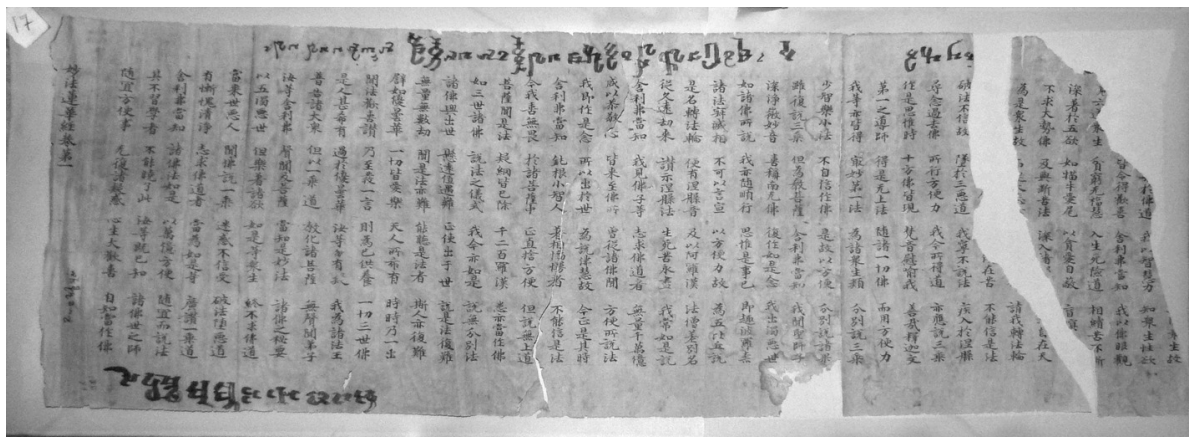

Pl. 35. ВФ-4190 recto. By courtesy of the State Hermitage

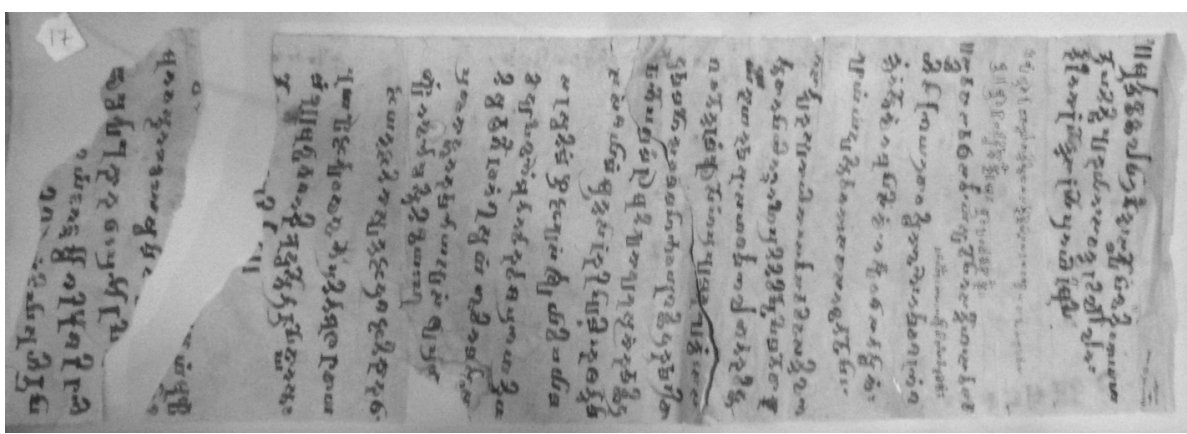

Pl. 36. ВФ-4190 verso. By courtesy of the State Hermitage

Inventory number: $\mathrm{B} \Phi-4190$.

Old finding number: T II Y 4 / T II Y 7.

Number of lines: recto (Chinese): $38+1$ headline, recto (Brāhmī): 3, verso (Brāhmī): $3+2+27$.

Size: $71.5 \mathrm{~cm} \times 26.6 \mathrm{~cm} ; 13.1 \mathrm{~cm} \times 26.1 \mathrm{~cm}$. 
(19) The 佛説佛名經 Foshuo foming jing (Buddhanama-sūtra) with multicoloured illuminations: Taishō vol. 14, no. 440, 175a 27 - b 5 (11th scroll) or Taishō vol. 14, no. 441, 283a 3-10 (25th scroll).

Identified by Tsuneki Nishiwaki.

Manuscript. Scroll format.

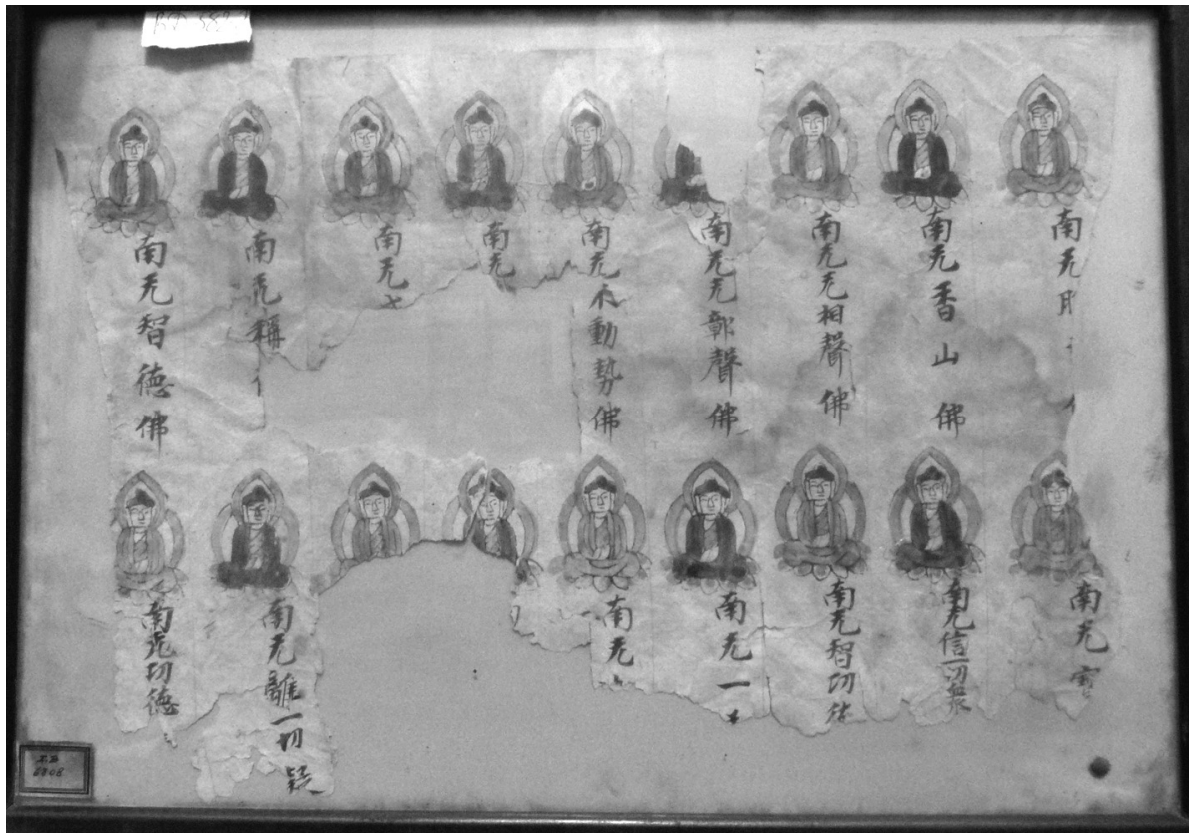

P1. 37. ВФ-4723. By courtesy of the State Hermitage

Inventory number: $\mathrm{B} \Phi-4723$.

Former inventory number: IB 6308.

Number of lines: $9+(1)$.

Size: $38.3 \mathrm{~cm} \times 25.8 \mathrm{~cm}$.

Reference: Staatliche Museen zu Berlin. Dokumentation der Verluste 2002, 275 (with ill.): „IB 6308 Chinesische Buchrolle mit «1000 Buddhas»“. 
(20) The Old Uighur version of the Lalitavistara Sütra ("Buddha Biography").

Manuscript. Scroll format.

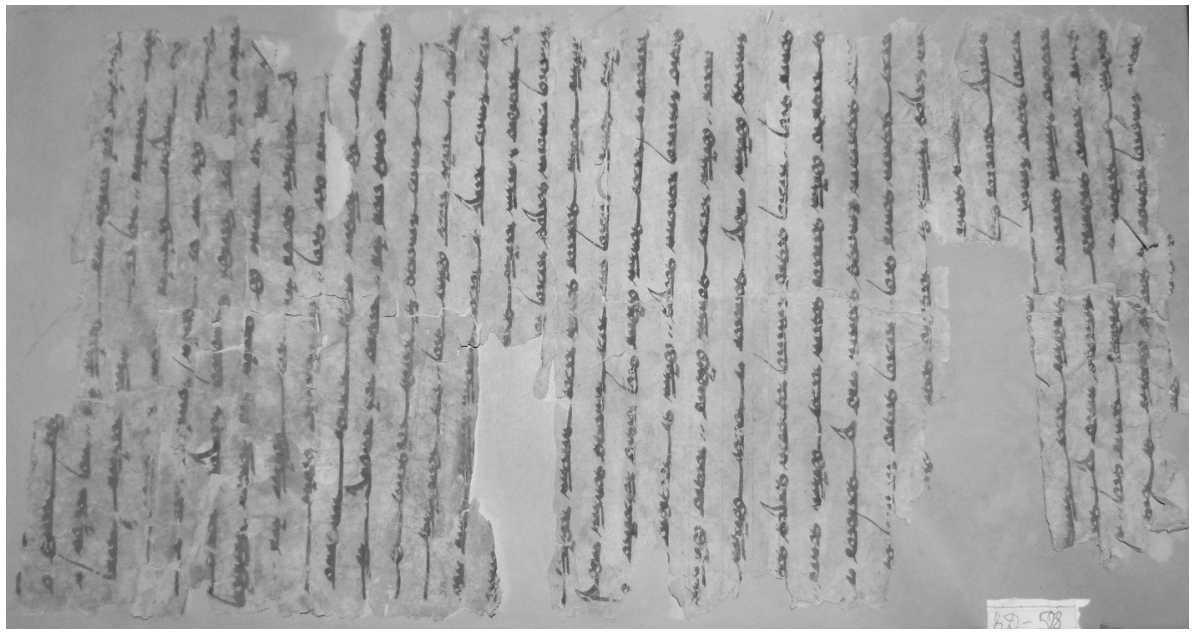

Pl. 38. ВД-528. By courtesy of the State Hermitage

Inventory number: ВД-528.

Old finding number: T II Y $32+$ T II Y $21\left(* * U 9371^{37}\right)$.

Number of lines: 36 .

Size: $57 \mathrm{~cm} \times 29 \mathrm{~cm}$.

Reference: MÜLLER 1911, 4-7 (text 1).

(21) The 佛説佛名經 Foshuo foming jing (Buddhanama-sūtra): Taishō vol. 14, no. 440, 169c 3 - 170a 16 (10th scroll) or Taishō vol. 14, no. 441, 274b 16 -274c 20 (22nd scroll). Identified by Tsuneki Nishiwaki.

Manuscript with prints of small, non-coloured Buddha images. Scroll format. $^{38}$

${ }^{37}$ Concerning the signature **U9371 see the explanation given for **U9232 in $\mathrm{fn} .10$.

${ }^{38}$ The fragment of this scroll consists of 5 sheets of paper glued together, as usual for these scrolls. The size of each (complete) paper sheet is: $43 \mathrm{~cm} \times 29.7 \mathrm{~cm}$. 


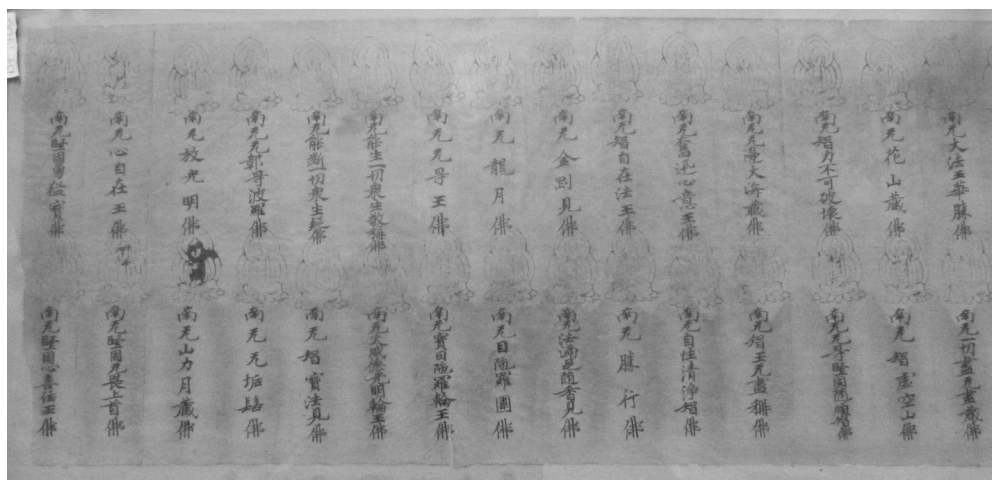

Pl. 39. ВФ-4200, the final part of the fragment. By courtesy of the State Hermitage

Inventory number: ВФ-4200.

Old finding number: [ ] Y 66.

Additional note: ящ 102, акт 99 от 27/Х п. $71 .{ }^{39}$

Number of lines: $37 .^{40}$

Size: $159.5 \mathrm{~cm} \times 29.7 \mathrm{~cm}$.

(22) Two fragments are framed together. Only one side of each fragment is visible. The back sides of both fragments are covered by the paperboard which is put in between them.

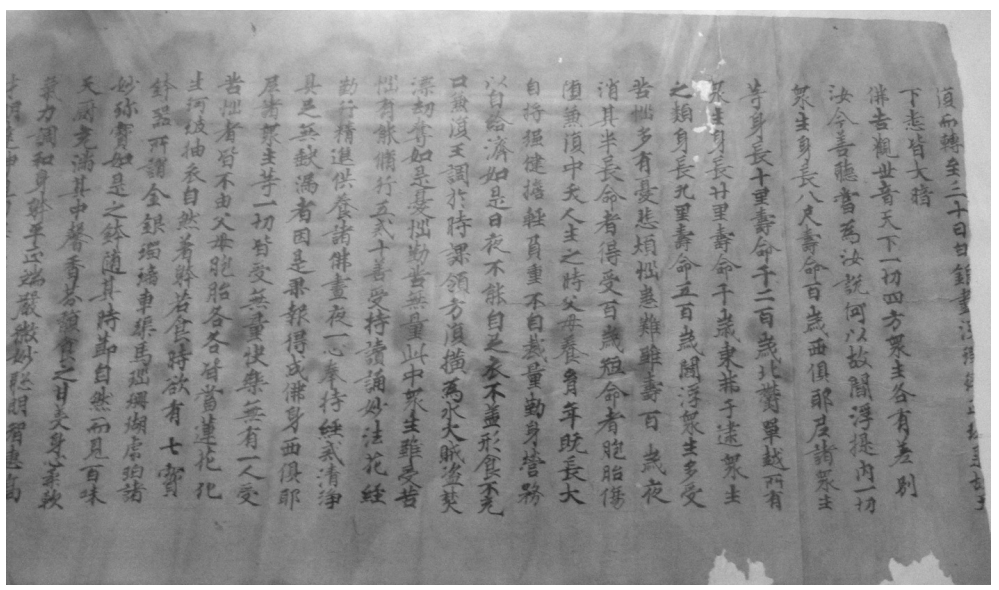

Pl. 40. ВФ-4194, beginning of fragment A. By courtesy of the State Hermitage

\footnotetext{
${ }^{39}$ For an explanation concerning the data of this additional note see fn. 12 .

${ }^{40}$ A note on the back of the frame reads as follows: „Rückseite Schrift“. Remains of this script is clearly visible on the recto side of the fragment between the Chinese text lines, but the back of the fragment is unfortunately covered.
} 
30

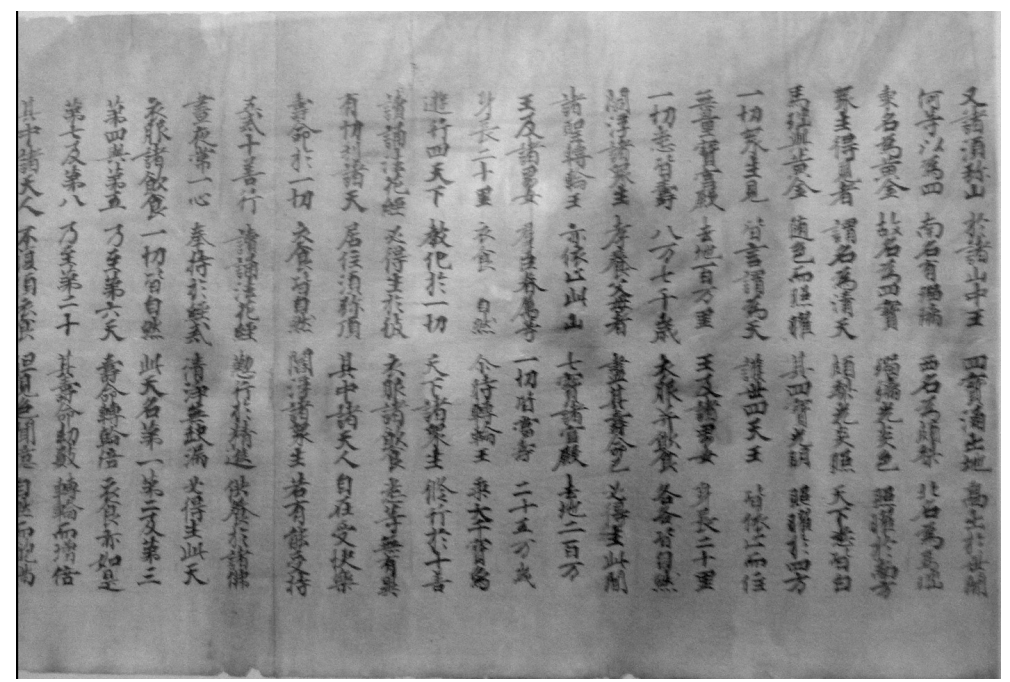

P1. 41. ВФ-4194, beginning of fragment B. By courtesy of the State Hermitage

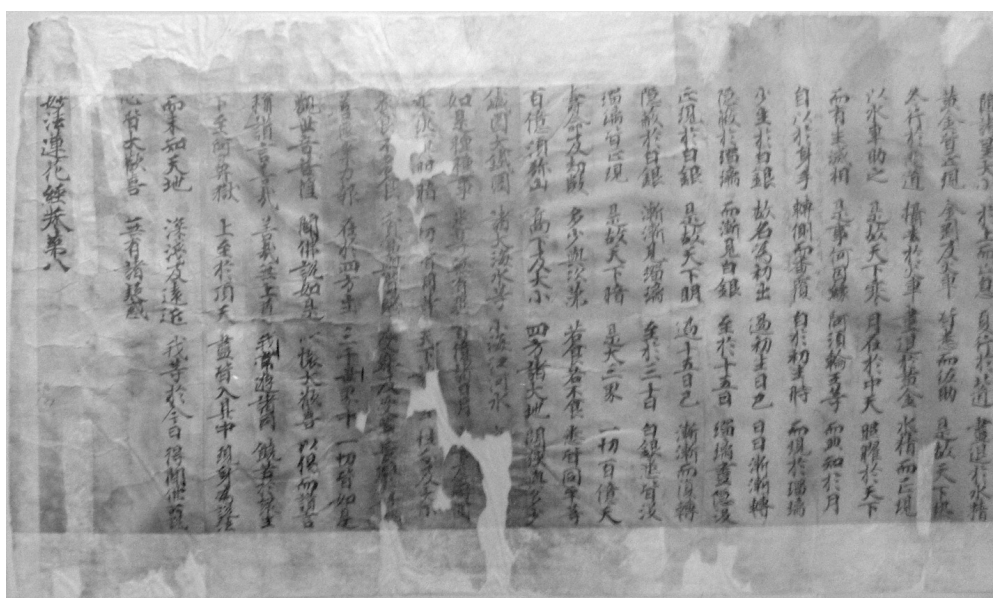

P1. 42. ВФ-4194, final part of fragment B. By courtesy of the State Hermitage

Fragment A: 妙法蓮華經度量天地品第二十九 Miaofa lianhua jing du liang tian di $\operatorname{pin}(\sim \mathrm{BD} 03917,14-8-14-11)$.

Manuscript. Scroll fragment. ${ }^{41}$

Fragment B: 妙法蓮華經度量天地品第二十九 Miaofa lianhua jing du liang tian di pin di er shi jiu ( BD 03917, 14-12-14-14).

Manuscript. Scroll fragment. Title at the end: 妙法蓮花經卷第八.

${ }^{41}$ This scroll fragment consists of 4 sheets of paper. There are 24 text lines on each (complete) sheet of paper. Each line has 16-19 characters. The length of each text line is $19.8 \mathrm{~cm}$. 
The complete manuscript of the 妙法蓮華經度量天地品第二十九 Miaofa lianhua jing du liang tian di pin di er shi jiu from Dunhuang is preserved in the National Library of China, Beijing under the shelf number BD 03917. For the incomplete Stein manuscript 1298 from Dunhuang see Taishō vol. 85, no. 2872, 1355c1356a.

Identified and annotated by Tsuneki Nishiwaki.

Inventory number: ВФ 4194.

Old finding number: Fragment A: none; Fragment B: T II Y 27.

Number of lines: Fragment A: 61 lines; Fragment B: $66+1$ head line.

Size: Fragment A: $108.2 \mathrm{~cm} \times 26.4 \mathrm{~cm}$; Fragment B: $121.2 \mathrm{~cm} \times 26.3 \mathrm{~cm}$.

(23) The 佛説佛名經 Foshuo foming jing (Buddhanama-sūtra).

Manuscript with prints of small, partly coloured Buddha images in scroll format.

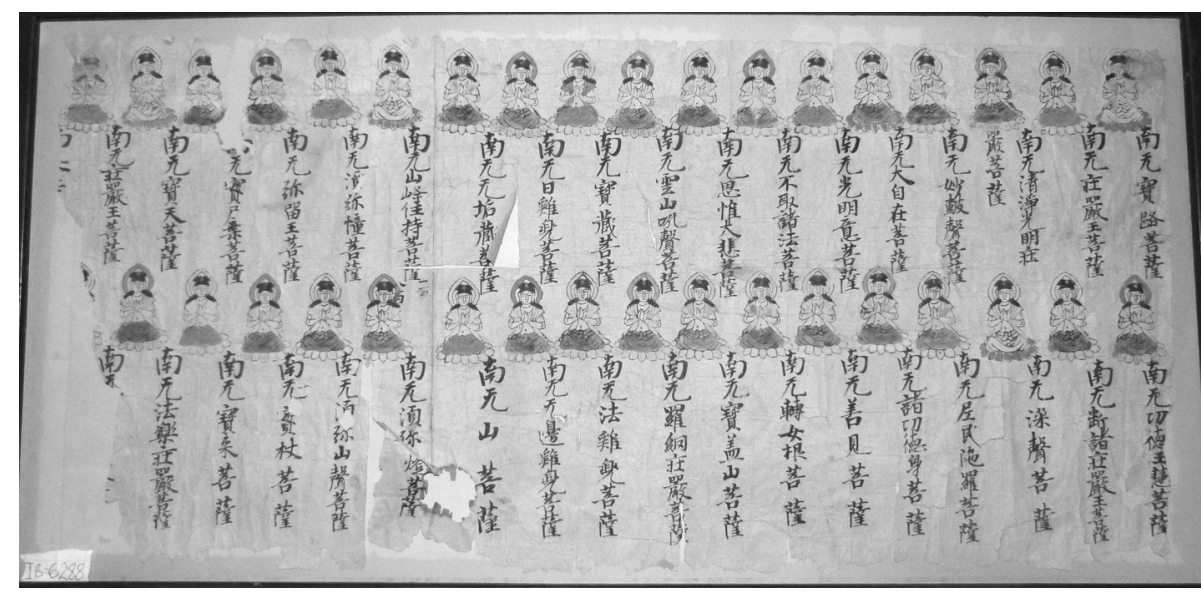

P1. 43. ВФ-4725. By courtesy of the State Hermitage

Inventory number: ВФ-4725.

Old finding number: $\mathrm{T}$ II $\mathrm{T}$.

Former inventory number: IB 6288.

Number of lines: 20 .

Size: $63.2 \mathrm{~cm} \times 30.0 \mathrm{~cm}$.

Reference: Staatliche Museen zu Berlin. Dokumentation der Verluste 2002, 275: „IB 6288 Chinesische Buchrolle mit «1000 Buddhas». Herkunft: Toyoq, Manuskript-Raum. Papiermalerei. Maße: unbekannt. 2. Turfanexpedition (1904-1905). Letzte Ausstellung: unbekannt, unpubliziert.“ 


\section{Appendix}

Edition of the Säkiz Yükmäk Yaruk fragment BФ-4201 (**U9232, T III TV 61/T III 84)

The preserved fragment is framed. The wooden frame makes it clear that this manuscript must have been on display in the exhibition's Turfan department of the Museum für Völkerkunde. On the top of the upper bottom line in red color there are added some line numbers in small pencil script. Probably it happened in the course of the work on this manuscript. The first number marked the tenth line. According to this numbering the first visible text line in the framed manuscript is line four. Probably the lines in front of this fourth line are covered by the frame.

It is because the full text of this fragment had been never edited before that in the following the text of this fragment is published here. Some quotations are present in the edition of W. Bang, A. von Gabain and G.R. Rachmati in Türkische Turfantexte VI (TT VI), which is the first edition of the full text of the Säkiz Yükmäk Yaruk (SYY). ${ }^{42}$ Another, much more important reason is that Juten Oda, who recently published an excellent and detailed study on this popular Old Uighur text, was not able to take this manuscript into consideration because it's surviving was still unknown at this date. In his investigation of the different Old Uighur manuscripts he was able to detect two main versions of the text which he subdivided into two subgroups each, i.e. text versions Ia and I b, as well as IIc and IId. By studying the text of the rediscovered manuscript, labelled as B 25 in TT VI, we are now able to note that Oda's text version IIc is the closest, but not completely identical one to the SYY text of the manuscript on hand. For the parallel text cf. BANG/GABAIN/RACHMATI 1934 (B 25) and ODA 2010, 117-140: 11. 151289 (Text volume). The most striking text variants are marked and a short comment is added in footnotes.

\section{Transcription}

(1)-(3) \{lines not more visible\}

(4) körklä . ön körk körür . ol ön körk tözi yıltızı yänä ${ }^{43}$

(5) yok kurug tetir. ol yokug bilir bilgä bilig ugrayu ${ }^{44}$ burhanlar

(6) biligi tetir : anı üčün tınl(1)g-lar ädgü köni yolčı yerči bulup

\footnotetext{
${ }^{42}$ BAng/Gabain/Rachmati 1934.

43 yänä: IIc, cf. ODA 2010, 117 1. 152 (Text volume).

44 ugrayu: IIc, cf. ODA 2010, 117 1. 153 (Text volume).
} 
(7) alku törög bälgüg ${ }^{45}$ yok körsär : ol tınl(1)g köyüli biligi burhan

(8) -lar-nı๊ ${ }^{46}$ könüli biligi tetir . k(a)ltı ınča körsär öjkörk

(9) ulatı altı türlüg yag1-ta ${ }^{47}$ kutrulur burhan kutın bulur . ol kim

(10) ön körk tetir . yok kurug ymä ol ok ärür . ol kim yok kurug

(11) tetir . ön körk ymä ol ok ärür öndä öni yok kurug bultukmaz

(12) yok kurug-ta ${ }^{48}$ öni ymä ön körk bultukmaz : ulatı ašamak sakınč

(13) k1lınč bilig alku inčä ök ${ }^{49}$ bilmiš ukmıš kärgäk . inčä ötgürü usar

(14) ötrü ol ok öy körk yänä tözün öylüg atl(1) $\mathrm{g}^{50}$ burhan tetir

(15) ymä kulgakı turkaru adrok adrok alkınčsız ün äšidür . ol kim ün

(16) tep tetir : yok kurug ymä ol ok ärür . ol kim yok kurug tetir ün

(17) ymä ol ok ärür : üntä öyi yok kurug bultukmaz . yok kurug-ta öyi

(18) ymä ün bultukmaz : inčä ötgürü usar ötrü ol ok ün yänä sukančıg

(19) ünlüg atl(1)g burhan tetir : ymä burunı turkaru adrok adrok alkınčsız

(20) yıdyıpar yıdlayur : ol kim yıdyıpar tetir : yok kurug ymä ol ok ärür :

(21) ol kim yok kurug tetir yıdyıpar ymä ol ok ärür . yıdyıpar

(22) -ta öni yok kurug bultukmaz yok kurug-ta öni ymä yıdyıpar

(23) bultukmaz : inčä ötgürü usar ötrü ol ok yıdyıpar yänä yıpar

(24) yükmäk atl(1)g burhan tetir . ymä tilin turkaru adrok adrok alkınč

(25) -siz tatiglig tatig tatar ol kim tatiglig tatıg tep tetir yok kurug

(26) ymä ol ok ärür : ol kim yok kurug tetir ${ }^{51}$ : tatılılıg ${ }^{52}$ tatıg ymä ol

(27) ok ärür : tatıg-ta ${ }^{53}$ öni yok kurug bultukmaz . yok kurug-ta ${ }^{54}$ öji

(28) ymä tatıglıg ${ }^{55}$ tatıg bultukmaz : inčä ötgürü usar ötrü ol ok

(29) tatıglıg tatıg yänä ${ }^{56}$ nom ögrünčü atl(1)g burhan tetir . ymä ätöz

(30) -i turkaru adrok adrok alkınčsız säviglig bürtmäk bürtär : ol

(31) kim bürtmäk tetir : yok kurug ${ }^{57}$ ymä ol ok ärür : ol kim yok kurug

(32) tetir : bürtmäk ymä ol ok ärür : bürtmäkdä ${ }^{58}$ öni yok kurug

${ }^{45}$ törög bälgüg is only attested here, cf. ODA 2010, 1171.154 (Text volume).

${ }^{46}$ burhanlarnin: only present in T-24, cf. ODA 2010, 117 footnote to line 155 (Text volume).

47 yagita: only attested here.

48 yok kurugta: IIc, cf. ODA 2010, 118 1. 159 (Text volume). Add -ta/-da here in 1. 159: yoq qurur $[$ talda]

$49 \ddot{o k}$ : IIc, cf. ODA 2010, 118 1. 161 (Text volume).

${ }^{50} \mathrm{atl}(\mathrm{l}) \mathrm{g}$ : only attested here, cf. ODA 2010, 1191.162 (Text volume).

${ }^{51}$ kurug tetir: IId, cf. ODA 2010, 1211.175 (Text volume).

52 tatıglig: IIc, cf. ODA 2010, 121 1. 175 (Text volume).

53 tatigta: IId, cf. ODA 2010, 121 1. 175 (Text volume).

${ }^{54}$ kurugta: IId, cf. ODA 2010, 1211.176 (Text volume).

${ }^{55}$ tatıglig: Ib, IIc (tatiglg), cf. cf. ODA 2010, 121 1. 176 (Text volume).

${ }^{56}$ ötrü ol ok tatıglig tatıg yänä: IIc, cf. ODA 2010, 1211 . 177 (Text volume). ötrü is additional added here.

57 yok kurug: Ia, IIc, cf. ODA 2010, 122 1. 179 (Text volume).

${ }^{58}$ bürtmäkdä: Ia, cf. ODA 2010, 1221.180 (Text volume). 
(33) bultukmaz : yok kurug-ta ${ }^{59}$ öyi ymä bürtmäk bultukmaz : inčä ötgürü

(34) usar ötrü ol ok bürtmäk yänä ${ }^{60}$ bilgä bilig yaltrıklıg atl(1)g

(35) burhan ${ }^{61}$ tetir : ymä könüli biligi ${ }^{62}$ turkaru $^{63}$ adrok adrok alkınčsız

(36) törö sakınur adırar ${ }^{64}:$ ol kim törö tep tetir ${ }^{65}$ : yok kurug ymä ol

(37) ok ärür: ol kim yok kurug tetir : törö ymä ol ok ärür : törö-tä ${ }^{66}$

(38) öni yok kurug bultukmaz yok kurug-ta ${ }^{67}$ öji ymä törö bultuk

(39) -maz : inčä ötgürü usar ötrü ol ok törö yänä ${ }^{68}$ nom yaltrıklıg

(40) atl(1)g burhan tetir : tözünlär ogl1-y-a iländäči ärksindäči

(41) atl(1)g altı kačıg-lar-nıy iši küdöki altı törlüg adkangu

(42) -lar birläki ${ }^{69}$ otgurak bälgüsi bo ärür : birök $^{70}$ kim kayu tınl(1)g-lar bolar

(43) -n1 ${ }^{71}$ ötgürü usar : yayılmadın köni orukča nomlasar turkaru

(44) üzüksüz išlätsär yayılmasar ötrü ${ }^{72}$ ol tınl(1)g burhan-lar yol

(45) -1na kirmiš-kä sanur : birök munı bilmädin ukmadın ${ }^{73}$ adınsıgrak

(46) adıra tutsar : azu t(ä)rs tätrü oruk-ča yanlok nomlasar ötrü ${ }^{74}$

(47) ol tınl(1)g-lar bo yertinčüdä tägzinür ${ }^{75}$ azu üč y(a)vlak yol-ta tüšär :

(48) sansız tümän ažunta tugar ölür taloy ügüz täg tärin ${ }^{76}$ ämgäk ämgän

(49) -ür : tözün-lärim ädgüg ayıgıg kertgünmiš k(ä)rgäk \{kägäk\} : kim ken ökünmä

(50) -sär ${ }^{77}$ : takı ymä tözün-lärim kamag tınl(1)g-lar-nıy köyüli ätözi

(51) burhan-lar-nı̣ nom idiši tetir : kim üč agılıg iki y(e)g(i)rmi

${ }^{59}$ yok kurugta: Ia, IIc (kurugda), cf. ODA 2010, 122 1. 181 (Text volume).

${ }^{60}$ ötrü ol ok bürtmäk yänä: IIc, cf. ODA 2010, 1221.182 (Text volume).

${ }^{61}$ bilgä bilig yaltriklig atl(l)g burhan: IIc, cf. ODA 2010, 1221.182 (Text volume). atl(i)g is additional added here.

62 ymä köyüli biligi: IIc, cf. ODA 2010, 123 1. 183 (Text volume).

${ }^{63}$ turkaru: Ia, Ib, cf. ODA 2010, 1231.183 (Text volume).

${ }^{64}$ törö sakınur adırar: Ib, cf. ODA 2010, 1231.184 (Text volume).

${ }^{65}$ tep tetir: only attested here.

${ }^{66}$ törö-tä: only attested here.

${ }^{67}$ kurug-ta: only attested here.

${ }^{68}$ ötrü ol ok törö yänä: IIc, cf. ODA 2010, 1231.188 (Text volume).

${ }^{69}$ atl(l)g burhan tetir : tözünlär ogll-y-a iländäči ärksindäči atl(l)g altı kačlg-lar-nıり iši küdöki altı törlüg adkangu-lar birläki: IIc, cf. ODA 2010, 123-124 11. 188-190 (Text volume).

${ }^{70}$ birök: IIc, cf. ODA 2010, 1241.191 (Text volume).

${ }^{71}$ bolar-nl: IIc, cf. ODA 2010, 1241.191 (Text volume).

${ }^{72}$ nomlasar turkaru üzüksüz išlätsär yaฑılmasar ötrü: IIc, cf. ODA 2010, 124 11. 192-193 (Text volume).

${ }^{73}$ bilmädin ukmadin: in the type of a binom only attested here.

${ }^{74}$ t(ä)rs tätrü oruk-ča yaylok nomlasar ötrü: IIc, cf. ODA 2010, 125 1. 196 (Text volume).

${ }^{75}$ bo yertinčüdä tägzinür: Ia, Ib, cf. ODA 2010, 125 1. 197 (Text volume).

${ }^{76}$ tüšär : sansız tümän ažunta tugar ölür taloy ügüz täg täriq: this additional text is only attested here.

77 ökünmä-sär: Ia, cf. ODA 2010, 125 1. 199 (Text volume). 
(52) bölök nomug tükädi ${ }^{78}$ köyülintä tutar : ančulayu k(a))ltı kägdätä ${ }^{79}$ bitimiš

(53) küün bitig täg sansız tümän ažuntabärü unıtmadın ıčgınmadın öyü

(54) sakınu tutar ugurı boltukda adınaku-ka bošgurur ulayur alkınčukadakı

(55) burhan-lar-nı̣ urugı üzülmäz kılča ägsümäz tägšilmäz busulmaz

(56) artamaz alkınmaz . ol barča ${ }^{80}$ burhan-lar-nın kömsüsi agılıkı tetir .

(57) kim könül bilir nom yıltızın köyül tözin körmiš bilmiš tınl(1)g

(58) -lar ärsär ${ }^{81}$ : ötrü ${ }^{82}$ ol temin anı körür anı bilir anı ötgürür anta

(59) -da öni arhant pratikabut ulatı šravak-lar kamag nizvani

(60) basmıš tınl(1)g-lar ${ }^{83}$ alku munı bilmäz ukmak-lar ${ }^{84}$ ötgürü ymä ${ }^{85}$ umaz

(61) -lar . tözün-lärim kim kayu tınl(1)g-lar bo nom bitigig okıp tüpsüz

(62) tärin yörügin ötgürü usar . ol tınl(1)g-lar-nı̄ ${ }^{86}$ könüli ätözi

(63) burhan-lar-nın nom idiši tetir : antada öyi yạlok sakınčlıg

(64) tınlıglar äsrök kiši täg muna tänä adınu umadın yạlok sakınč

(65) turgursar [i]nčä bilmäsär bo mänin öz könülüm ätözüm burhan

(66) -lar-nı[y] nom tözi yıltızı ärür tep : ötgürü umasar ${ }^{87}$ ötrü ol

(67) tınlıg-lar bo yertinčüdäki ügüz-tä tägzinür-čä čomar batar tägz

(68) -inür $\mathrm{azu}^{88}$ üč y(a)vlak yol-ta tugar sansız tümän ažunta tugar ölür

(69) taluy ügüz täg tärị ämgäk ${ }^{89}$ ämgänür : burhan-lar-nı̣ nomın atın

(70) ymä äšị̣mäz : ol üdün beš yüz t(ä)yri oglanı ol kuvrag-ta ${ }^{90}$ ärür ärdi

(71) -lär : t(ä)nri t(ä)yrisi burhan-ta antag adınčıg muyadınčıg ${ }^{91}$ sukančıg

(72) tatıglıg nom äšidip nom közläri ${ }^{92}$ alku arıtı ačıltı ögirti

(73) -[lä]r sävinti-lär ${ }^{93}$ : alkugun tüzgärinčsiz yeg tüzü köni tuymak

(74) burhan kutına könül turgurdı-lar : ol üdün tıdıgsız bodis(a)t(a)v

(75) t(ä)Đri [tän] grisi burhan-ka ${ }^{94}$ inčä tep ötüg ötünti : $t(a ̈) \eta r i m ~ b o$

${ }^{78} t \ddot{u} k a ̈ d i$ : only attested here. Ia, Ib, IIc: tükäti, cf. ODA 2010, 126 1. 202 (Text volume).

${ }^{79}$ kägdätä: only attested here. Ia, Ib, IIc: kägdäkä, cf. ODA 2010, 126 1. 202 (Text volume).

${ }^{80}$ barča: this additional text is attested only here.

${ }^{81}$ körmiš bilmiš tınl(l)g-lar ärsär: IIc, cf. ODA 2010, 127 1. 208 (Text volume).

82 ötrü: exclusively added here.

${ }^{83}$ tınl(l)glar: attested only here.

${ }^{84}$ ukmaklar: attested only here. Two dots are added to mark the final letter of $u k m a k$ as $-\mathrm{Q}$.

${ }^{85}$ ymä: exclusively added here.

${ }^{86}$ tınl( $\imath$ )glarnin: attested only here.

${ }^{87}$ ötgürü umasar: exclusively added here.

${ }^{88}$ azu: exclusively added here.

${ }^{89}$ taluy ügüz täg täri门 ämgäk: attested only here. Ib, IIc: taluy ügüztä ämgäk.

${ }^{90}$ kuvragta: attested only here. Ia, Ib, IIc: kuvragda.

${ }^{91}$ muyadınčlg: IIc, cf. ODA 2010, 1291.222 (Text volume).

92 nom közläri: Ia, Ib, cf. ODA 2010, 129 1. 223 (Text volume).

93 alku arıtı ačlltı ögirti[lä]r sävintilär: IIc (ögirdi sävintilär), cf. ODA 2010, 129 1. 223

(Text volume).

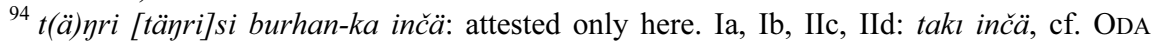
2010, 129 1. 225 (Text volume). 
(76) yerti[nč]üdäki kamag tınl(1)g-larta tugmak ölmäk bo iki törlüg

(77) törö ärtijü agır tetir : tugdukta kün tal[ulamaz] üdi kältükdä

(78) ötrü tugar : öltükdä ymä kün talulamaz : üd[i t]ägdüktä ötrü

(79) ölür : nä üčün yänä ölüg k(ä)rgäksiz yıdıg ätöz üčün ädgü kün

(80) ädgü üd talulayur ${ }^{95}$ : ädgü künkä ädgü üdkä temin tašgarur-lar ${ }^{96}$ :

(81) ulug törö toku kılur-lar ${ }^{97}$ törö toku kılmıš-ta ken yänä söki ol

(82) ok ävdä barkda ada tuda bolmadın barmaz : ig agrıg ölüm itim ${ }^{98}$

(83) [bolu]r : agı barım sačılur tökülür takı antag bolur : ol kapıg tunar

(84) nä tusu boltı ${ }^{99}$ ol ädgü kün ädgü üd körmiši : amtı t(ä)Đrim bo

(85) muntag t[ärs] biliglig ${ }^{100}$ ayıg kılınč-lıg t(1)nlıg-larka köni yol oruk körgitü

(86) birg[äy ä]rti : kim köni yolča kö[n]i orukča yorızun-lar ärti :

(87) tärs tätrü törö-sin kotzun-lar ärti t(ä)Đrim : t(ä)yri t(ä)Đrisi burhan

(88) inčä tep yarlıkadı ${ }^{101}$ : sadu sadu tıdıgsız bodis(a)t(a)v sız t(1)nlıg-lar

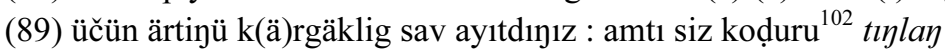

(90) [otguratı nomla]yu beräyin : ymä bo yerli t(ä)Đrili ärsär yetinčsiz

(91) [yetiz key] alkıg ${ }^{103}$ arıg turug yazınčsız ärür : kün-li ay-lı ärsär

(92) [ärtin]ü yaruk yašuk ädgü kılınčlıg alku-ka y(a)vlaksız tetir ${ }^{104}$ üd

(93) -li kolu-lı yıl-lı takı artokrak ädgü ärtijü yavaš $\{k i m\}\}^{105}$-kä ärsär ${ }^{106}$ nän

(94) y(a)vlakı yok adrok adrok tägšilmäki idi yok : tözün-lärim ${ }^{107} b[0]$

(95) yertinčüdäki eliglär han-1[a] $\mathrm{r}^{108}$ tegmä barča bodis(a)t(a)v-lar tetir : t[1nlıg]

(96) -lar üčün ätöz tägšürüp kälir-lär ${ }^{109}$ : ol elig-lär han-lar ymä alkuka

(97) y(a)rlıkančučı könül-lüg üčün kamag bodunug inčä igidür kaltı ög

95 ädgü kün ädgü üd talulayur: exclusively attested here.

${ }^{96}$ tašgarurlar: Ia, cf. ODA 2010, 130 11. 230-231 (Text volume).

${ }^{97}$ kılurlar: attested only here.

98 ölüm itim: attested only here.

99 ol kapıg tunar nä tusu boltt: IIc, cf. ölüm itim

${ }^{100}$ t[ärs] biliglig: IIc, cf. ODA 2010, 131 1. 236 (Text volume).

${ }^{101}$ t(ä)yri t(ä)yrisi burhan inčä tep yarlıkadr: Ia, Ib, cf. ODA 2010, 131 11. 238-239 (Text volume).

102 koduru attested only here. Ia, Ib, IIc: koduru, cf. ODA 2010, 131 1. 240 (Text volume).

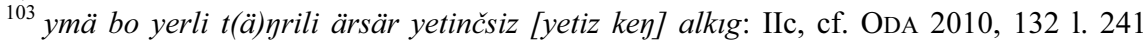

(Text volume).

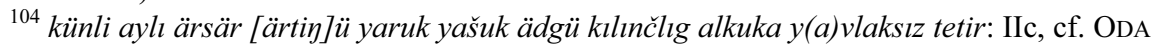
2010, 132 11. 242-244 (Text volume).

105 The place for this subsequent addition is marked with the sign "+".

106 ärsär: IIc, cf. ODA 2010, 133 1. 246 (Text volume).

107 tözünlärim: IIc, cf. ODA 2010, 133 1. 247 (Text volume).

108 b[o] yertinčüdäki eliglär hanl[a]r: IIc, cf. ODA 2010, 133 11. 247-248 (Text volume).

109 t[lnlıg]lar üčün ätöz tägšürüp kälir-lär: exclusively attested here. 


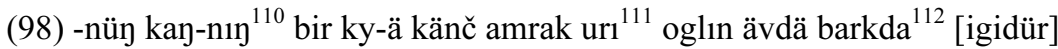

(99) -čä bodun-ka näy y(a)vlak sakınčı yok üstürdi ${ }^{113}$ kodı inär-lär [kamag]

(100) bodun-nuy ögi kayı bolgu üčün ötrü bo yertinčüdäki ulu[š]

(101) balık törösin etä ayu berür-lär ${ }^{114}$ : ayıg kılınčlar tınl(1)g-larıg iyär [basar] ${ }^{115}$

(102) kıy(1)n kızgut turgurur-lar : ö[tr]ü k[a]mag bodun-ka [ ]

(103) tep bitig bitiyür-lär : kü[n ] kolu [

(104) [ulu]š balık ${ }^{116}$ sayu ayu berü[rlär

(105) $\mathrm{k}(\mathrm{a}) \mathrm{lt}_{1}{ }^{117}$ tolu tep : tüz t[ep

(106) ketärmäk tep : tutmak tep [

(107) ornanmak tep : turgurmak $t\left[e p^{118}\right.$

(108) -äki užik bitiglärig ${ }^{19} \mathrm{~T}[$

(109) k1lgu üčün t(ä) $g^{120}$ anča munča T[

(110) k(ä)ntü [n]äy ketärü umazlar ${ }^{121}: a d[a$

(111) [ ] ]či körümči yultuzč [1

(112) [ amž]u tegmä al čäv[iš

(113) [ ] ]WRWR ///[

(114) [ $\quad y \ddot{a}] k^{\prime} i \check{c} g a ̈ k$ y[änä

(115) [ kl]lur: tak1/[

(116) [] bilmäz ukmazlar : ötrü [

(117) [täy]rili yerli körgitü ${ }^{122}$ [

(118) [ ]R: kün-li ay-l1-nın ${ }^{123}$ [

(119) [ ] key alkıg ulug [

(120) y[o]l-ka kermiš-kä sanur : är[tiøü

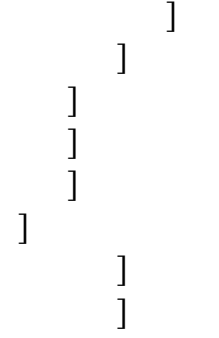

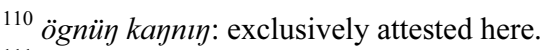

${ }^{111}$ känč amrak url: IIc, cf. ODA 2010, 133 1. 250 (Text volume).

112 barkda: attested only here. Ia, Ib, IIc: barkta.

113 yok üstürdi: IIc, cf. ODA 2010, 133-134 11. 251-252 (Text volume).

114 etä ayu berürlär: IIc, cf. ODA 2010, 134 1. 254 (Text volume).

115 aylg kllınčlar tınl(l)g-larıg iyär [basar] kly(l)n kızgut turgurur-lar: in case, the reading is correct, this text version is attested only here.

${ }^{116}$ The L-hook is not visible. Two sheets of paper are glued together at this position of the text and because of the overlapping of the two sheets, the L-hook is now covered by the subsequent page.

${ }^{117} k(a) l t r$ : attested only here.

118 ornanmak tep : turgurmak $t[$ ep ... attested only here. Ia, Ib, IIc: ornanmak tep turmak tep turgurmak tep, cf. ODA 2010, 135 1. 260 (Text volume).

${ }^{119}$ užik bitiglärig: IIc, cf. ODA 2010, 135 1. 261 (Text volume).

${ }^{120} t(\ddot{a}) g$ : attested only here.

${ }^{121}$ umazlar: attested only here. Ia, Ib, IIc, IId: umaz, cf. ODA 2010, 135 1. 263 (Text volume).

122 [täy]rili yerli körgitü: IIc, cf. ODA 2010, 137 1. 270 (Text volume).

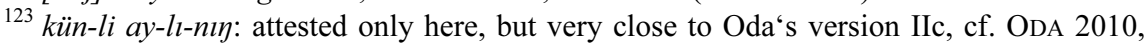
1371.272 (Text volume). 
(121) oglum kim kayu tınl(1)g tugsar [

(122) -un ol ogul ögin ämgätmäd[in

(123) bilgä igsiz ämgäksiz ada[sız

(124) kim kayu tınl(1)g ölsär ${ }^{124}$ ymä [

(125) keninä näy ada tuda bolm[agay] T/[

(126) ay-lar takı ädgü yıl yıl-ka ${ }^{125}$ kältä[či

(127) takı tözün ärtinü yavaš : bitig okıp [

(128) tuda bolgusı yok : ölüg-kä törö toku[

(129) -ig [ü]č kata okızun ärtinü kutadur /[ ]

(130) bolur : ol äv ${ }^{126}$ kün küninä yokaru asılur [

(131) kotsar burhan-lar yeriyä barır-lar ${ }^{127}: \operatorname{tak}[1$

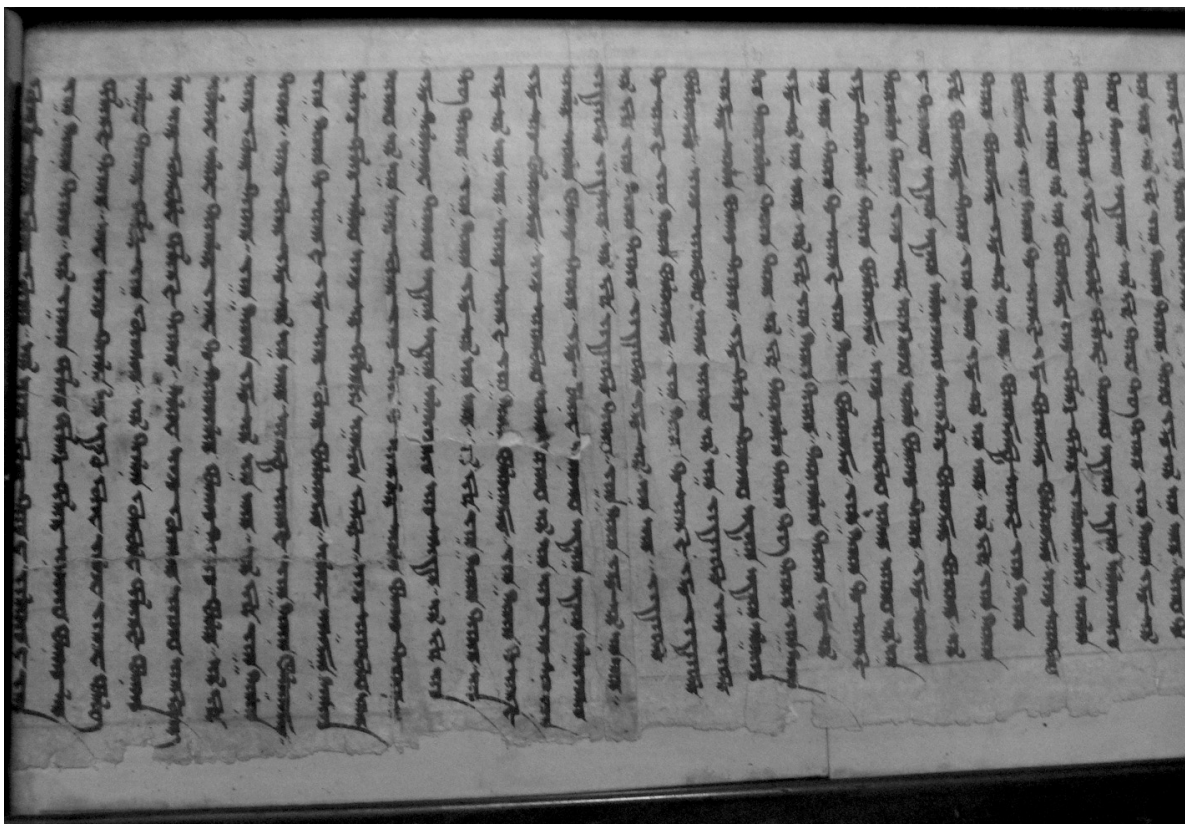

Pl. 44. ВФ-4201, 11. 4-37. By courtesy of the State Hermitage

${ }^{124}$ kim kayu tınl( $($ ) g ölsär: attested only here, but very close to Oda's version IIc, cf. ODA 2010, 139 1. 280 (Text volume).

${ }^{125} \mathrm{yl}$-ka: attested only here and Pli-7, cf. ODA 2010, 139: footnote to 1. 282 (Text volume).

${ }^{126} \ddot{a} v$ : hardly readable. The ink is faded out. Ia, Ib, IIc: $\ddot{a} v$ bark, cf. ODA 2010, 1401.287 (Text volume).

127 burhan-lar yeriyä bartr-lar: attested only here. 


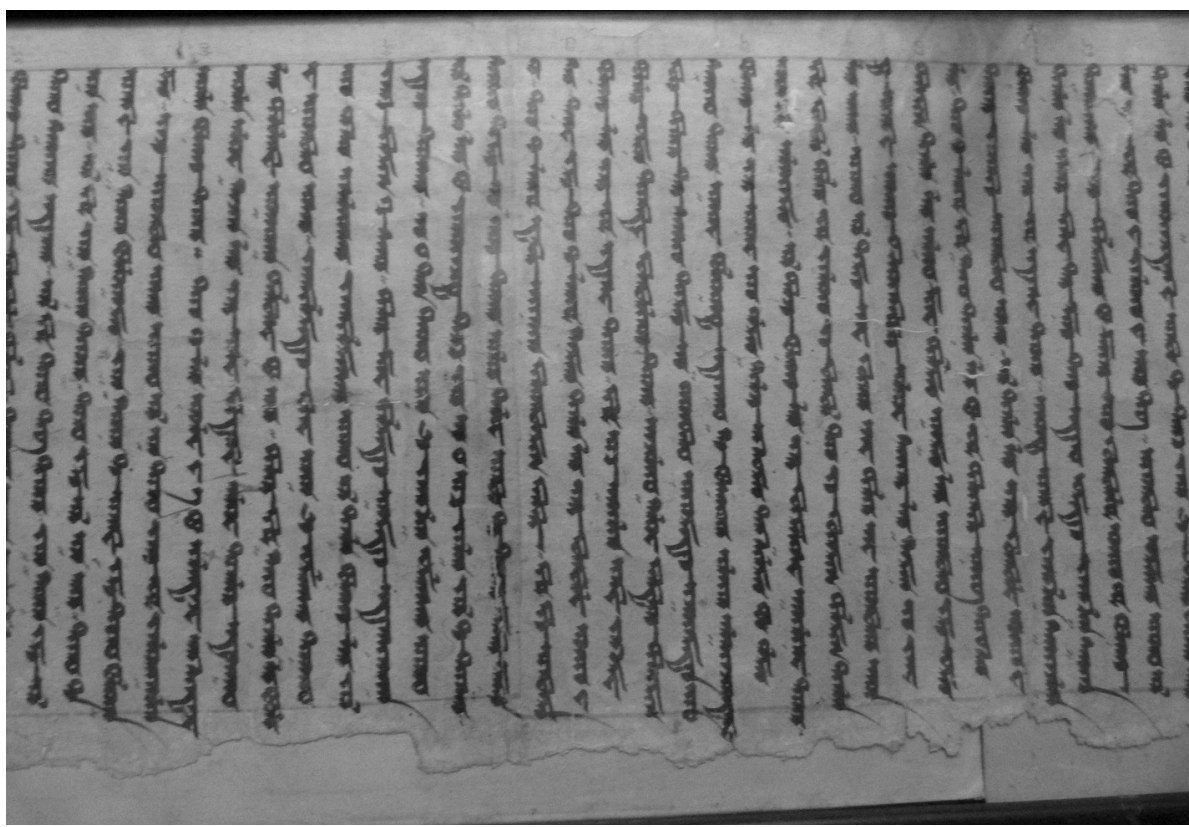

Pl. 45. ВФ-4201, 11. 36-66. By courtesy of the State Hermitage

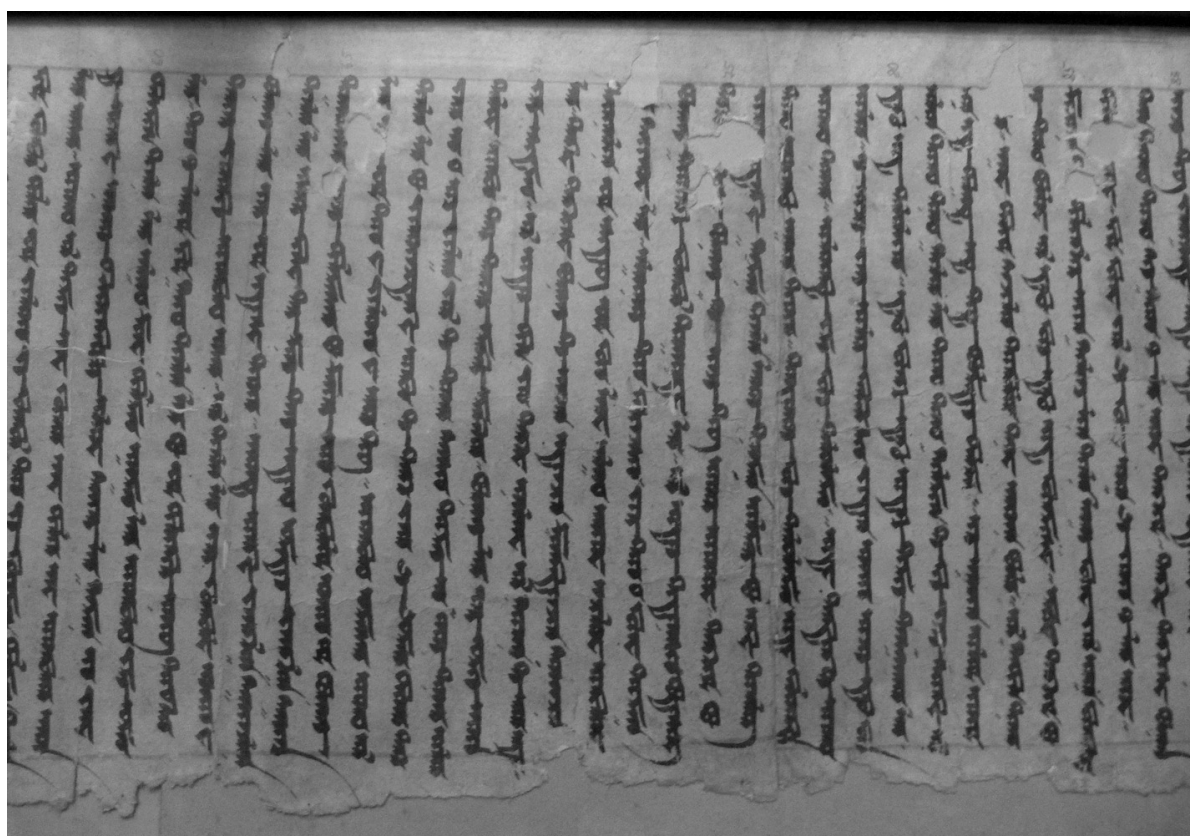

Pl. 46. ВФ-4201, 11. 58-87. By courtesy of the State Hermitage 


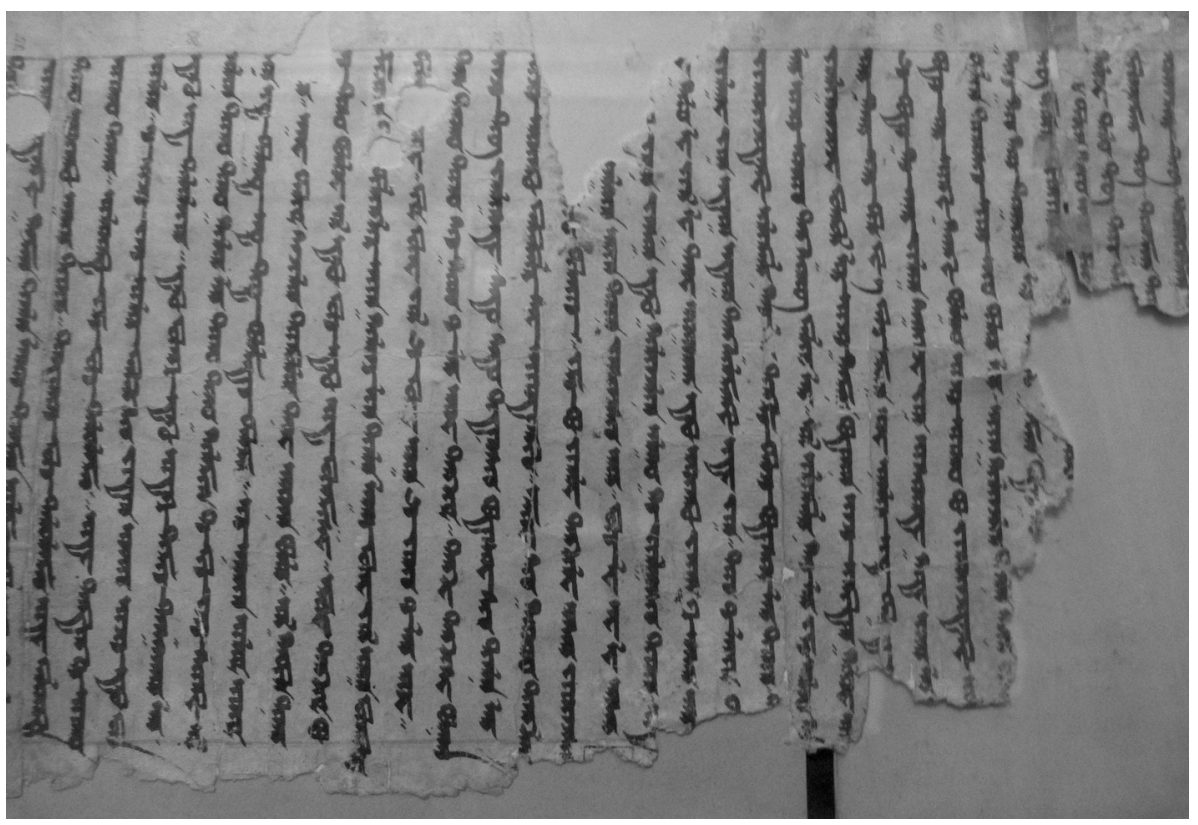

Pl. 47. ВФ-4201, 11. 77-106. By courtesy of the State Hermitage

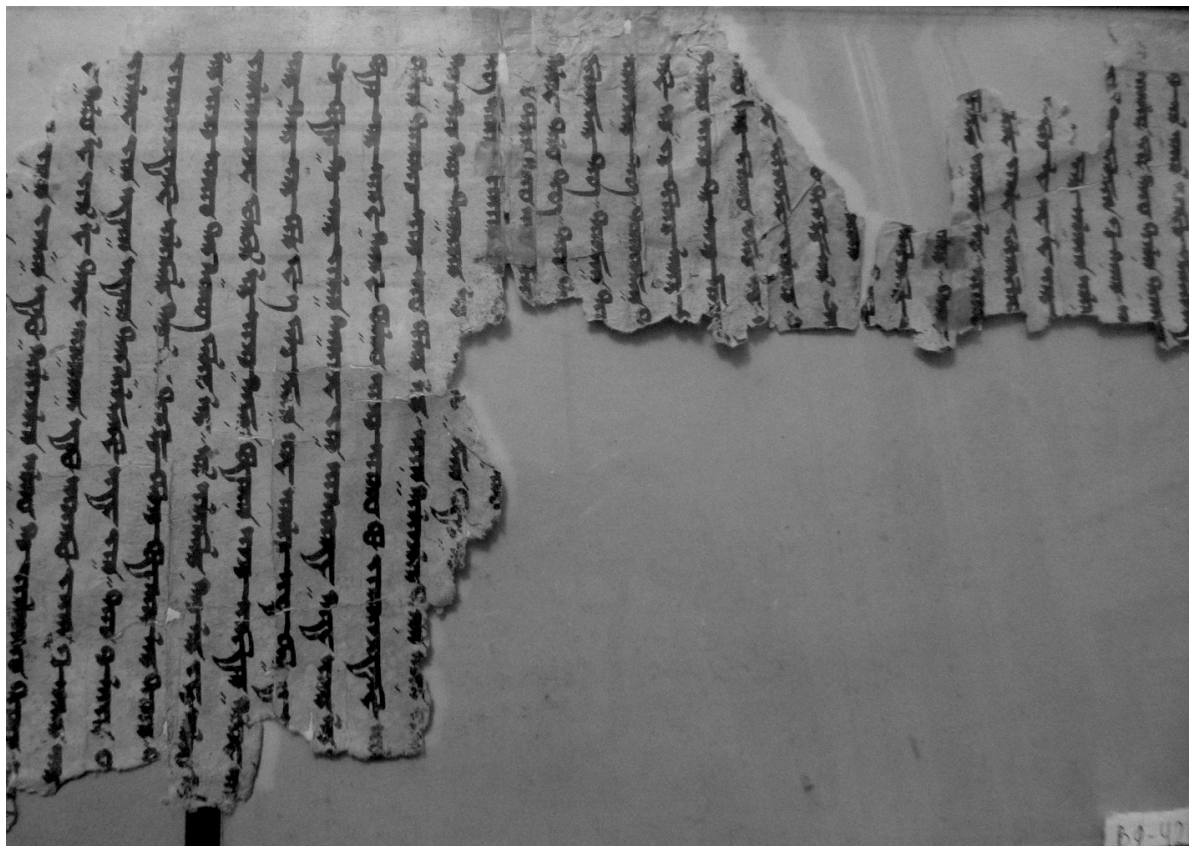

P1. 48. ВФ-4201, 11. 93-121. By courtesy of the State Hermitage 


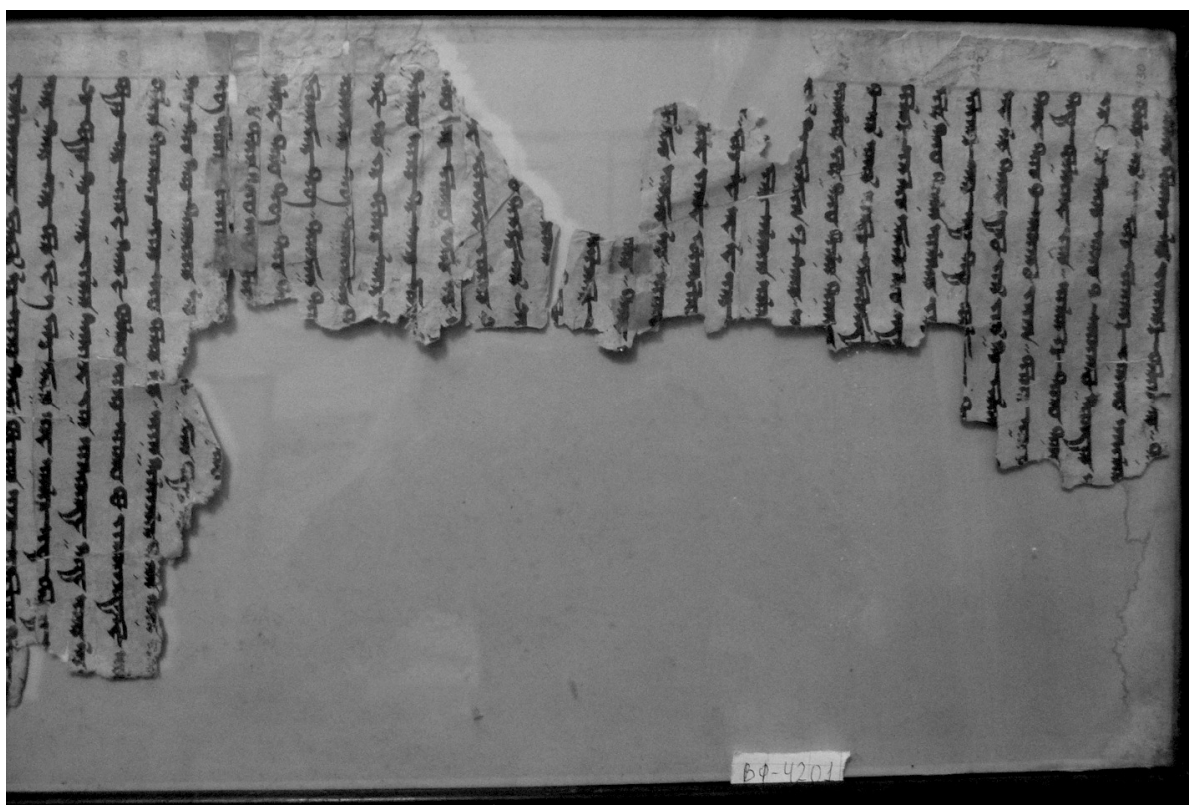

P1. 49. ВФ-4201, 11. 98-131. By courtesy of the State Hermitage

\section{References}

BAng, Willi and Gabain, Annemarie von and Rachmati, Gabdul Rašid 1934: Türkische Turfantexte. VI. Das buddhistische Sūtra Säkiz Yükmäk. Berlin: Verlag der Akademie der Wissenschaften (Sitzungsberichte der Preussischen Akademie der Wissenschaften. Phil.hist. Kl. 1934: 10) [Reprint in: Sprachwissenschaftliche Ergebnisse der deutschen TurfanForschung. Band 2. Leipzig: Zentralantiquariat der Deutschen Demokratischen Republik 1972, 190-289].

GraPOW, Hermann 1950: Die Begründung der Orientalischen Kommission von 1912. Aus der Geschichte der Akademie in den letzten fünfzig Jahren. Berlin: Akademie Verlag (Deutsche Akademie der Wissenschaften zu Berlin. Vorträge und Schriften. Heft 40).

KARA, Georg and ZIEME, Peter 1986: „Die uigurische Übersetzung des apokryphen Sūtras „Fo ding xin da tuo luo ni“. Altorientalische Forschungen 13, 2, 318-376.

KNÜPPEL, Michael 2013: Alttürkische Handschriften. Teil 17: Heilkundliche, volksreligiöse und Ritualtexte. Stuttgart: Franz Steiner Verlag (Verzeichnis der Orientalischen Handschriften in Deutschland 13, 25).

LE CoQ, Albert von 1911: Chuastuanift, ein Sündenbekenntnis der manichäischen Auditores. Gefunden in Turfan (Chinesisch-Turkistan). Berlin: Verlag der Akademie der Wissenschaften (Abhandlungen der Preußischen Akademie der Wissenschaften. Phil.-hist. Cl. 1910. Anhang: Abhandlungen nicht zur Akademie gehöriger Gelehrter 4).

LE COQ, Albert von 1919: „Kurze Einführung in die uigurische Schriftkunde“. Mitteilungen des Seminars für Orientalische Sprachen an der Friedrich-Wilhelms-Universität zu Berlin. 
Westasiatische Studien 11. 93-109 [Reprint in: Sprachwissenschaftliche Ergebnisse der deutschen Turfan-Forschung. Band 3. Leipzig: Zentralantiquariat der Deutschen Demokratischen Republik 1985, 519-537].

MüLLER, Friedrich Wilhelm Karl 1911: Uigurica II. Berlin: Verlag der Akademie der Wissenschaften (Abhandlungen der Königlich Preussischen Akademie der Wissenschaften. Phil.-hist. Cl. 1910: 3) [Reprint in: Sprachwissenschaftliche Ergebnisse der deutschen Turfan-Forschung. Vol. 1. Leipzig: Zentralantiquariat der Deutschen Demokratischen Republik 1972, 61-168].

NISHIWAKI Tsuneki 2008: "Besuche in Berlin - Verdienste eines japanischen Gelehrten aus der Zeit vor dem 2. Krieg“. Zeitschrift der Deutschen Morgenländischen Gesellschaft $158(2), 389-400$.

ODA Juten 2010: Bussetsu tenchi hachiyō shinjukyō ikkan torukogoyaku no kenkyū 仏説天地 八陽神呪経一巻 トルコ語訳の研究 [Engl. Nebentitel: A Study of the Buddhist Sūtra Called Säkiz yükmäk yaruq or Säkiz törlügin yarumïs yaltrïmïš in Old Turkic. Text Volume (hier: I), Facsimile Volume (hier: II). Kyōto: Hōzōkan.

ÖZBAY Betül 2014: Huastuanift. Manihaist Uygurların Tövbe Duası. Ankara: Türk Dil Kurumu (Atatürk Kültür, Dil ve Tarih Yüksek Kurumu. Türk Dil Kurumu Yayınları 1127).

ÖZERTURAL Zekine 2012: Alttürkische Handschriften. Teil 16: Mahāyāna-Sūtras und Kommentartexte. Stuttgart: Franz Steiner Verlag (Verzeichnis der Orientalischen Handschriften in Deutschland 13, 24).

Peshchery tysiachi budd. Rossiiskie èkspeditsii na Shelkovom puti. K 190-letiiu Aziatskogo Muzeja. Katalog vystavki [The Caves of One Thousand Buddhas. Russian Expeditions along the Silk Route. On the Occasion of 190 Years of the Asiatic Museum. Exhibition Catalogue] St. Petersburg: The State Hermitage Publishers 2008.

Rachmati Gabdul Rašid 1937: Türkische Turfan-Texte. VII. Mit sinologischen Anmerkungen von Dr. Wolfram Eberhard. Berlin: Verlag der Akademie der Wissenschaften (Abhandlungen der Preussischen Akademie der Wissenschaften. Phil.-hist. Kl. 1936: 12).

Raschmann, Simone-Christiane 2012: Alttürkische Handschriften. Teil 18: Buddhica aus der Berliner Turfansammlung. Teil 1: Das apokryphe Sutra Säkiz Yükmäk Yaruk. Mit einem Appendix von Rischel Anna-Grethe: Old Turkish Fragments from the Berlin Turfan Collection. Paper analysis of 62 manuscripts and block prints. Stuttgart: Franz Steiner Verlag (Verzeichnis der Orientalischen Handschriften in Deutschland 13, 26).

RÖHRBORN, Klaus and RÓNA-TAS, András 2005: Spätformen des zentralasiatischen Buddhismus. Die altuigurische Sitātapatrā-dhāraṇ̄, herausgegeben, übersetzt und kommentiert. Göttingen (Nachrichten der AdW zu Göttingen. I. Philologisch-historische Klasse. Jahrgang, No. 3).

Staatliche Museen zu Berlin. Dokumentation der Verluste 2002: Staatliche Museen zu Berlin. Dokumentation der Verluste. Band III. Verzeichnis seit 1945 vermisster Bestände der ehemaligen Indischen Abteilung des Museums für Völkerkunde, des heutigen Museums für Indische Kunst. Bearbeitet von Caren Dreyer, Lore Sander and Friederike Weis. Berlin.

TAube, Manfred 1980: Die Tibetica der Berliner Turfansammlung, Berlin: Akademie Verlag (Berliner Turfantexte X).

TEKIN Şinasi 1960: Uygurca metinler. Kuanşi im pusar (Ses Işiten Ilâh). Vap hua ki atllğ nom çeçeki sudur (Saddharmapuṇ̣̂īka-sūtra). Erzurum-Ankara: Türk Tarih Kurumu Basımevi.

WiLKENS, Jens 2000: Alttürkische Handschriften. Teil 8: Manichäisch-türkische Texte der Berliner Turfansammlung. Stuttgart: Franz Steiner Verlag (Verzeichnis der Orientalischen Handschriften in Deutschland 13, 16). 
WiLKENS, Jens 2003: Alttürkische Handschriften. Teil 9: Buddhistische Beichttexte. Stuttgart: Franz Steiner Verlag (Verzeichnis der Orientalischen Handschriften in Deutschland 13, 17).

YAKUP Abdurishid and KNÜPPEL, Michael 2007: Alttürkische Handschriften. Teil 11: Die uigurischen Blockdrucke der Berliner Turfansammlung. Teil 1: Tantrische Texte. Stuttgart: Franz Steiner Verlag (Verzeichnis der Orientalischen Handschriften in Deutschland 13, 19).

YAKUP Abdurishid 2009: Alttürkische Handschriften. Teil 12: Die uigurischen Blockdrucke der Berliner Turfansammlung. Teil 2: Apokryphen, Mahāyāna-Sūtren, Erzählungen, magische Texte, Kommentare und Kolophone. Stuttgart: Franz Steiner Verlag (Verzeichnis der Orientalischen Handschriften in Deutschland 13, 20).

YALDIZ, Marianne 2005: „A Journey of Exploration. Objets d'Arts of the Museum of Indian Art, Berlin, in the State Hermitage, St. Petersburg“. IDP News, 25 (Spring 2005), 2-3.

ZIEME, Peter 1975: Manichäisch-türkische Texte. Texte, Übersetzung, Anmerkungen. Berlin: Akademie Verlag (Schriften zur Geschichte und Kultur des Alten Orients. Berliner Turfantexte V).

ZIEME, Peter 2005: Magische Texte des uigurischen Buddhismus. Turnhout: Brepols (Berliner Turfantexte 23) 